ROCZNIKI HUMANISTYCZNE

Tom LXIX, zeszyt $2-2021$

DOI: https://doi.org/10.18290/rh21692-3

\title{
KOŚCIÓŁ KATOLICKI WE FRANCUSKOJĘZYCZNYCH UJĘCIACH HISTORII - GEOGRAFII - KULTURY POLSKI/RZECZYPOSPOLITEJ OPRACOWANYCH WE FRANCJI W LATACH 1835-1842 PRZEZ EMIGRANTÓW POLSKICH
}

Jednym $\mathrm{z}$ ważnych pod względem propagandowym (i finansowym) przedsięwzięć, zrealizowanych w latach 1835-1842, a zatem jeszcze w pierwszym dziesięcioleciu po powstaniu listopadowym, przez polskich emigrantów przebywających we Francji, było opublikowanie w Paryżu trzech obszernych dzieł przedstawiających zarazem historię, geografię i dorobek kulturowy ich zniewolonej Ojczyzny, a przeznaczonych dla czytelnika francuskojęzycznego (i nie tylko dla niego). Stanowiły, trzeba podkreślić, chlubne świadectwo ówczesnego rozmachu życia kulturalnego i wysiłków organizacyjnych środowiska wychodźstwa - Polaków, którzy wyemigrowali do Francji po powstaniu, jak i tych, którzy wcześniej znaleźli się $\mathrm{w}$ tym państwie ${ }^{1}$. Zostały poprzedzone w I połowie lat trzydziestych francuskojęzycznymi publikacjami, również opracowanymi przez polskich emigrantów, ukazującymi w mniejszym zakresie wspomnianą tematykę ${ }^{2}$. W formie niejako monumentalnej zaprezentowało ją natomiast

Prof. dr hab. LESZEK WoJCIECHOWSKI - Katedra Historii Starożytnej, Bizantyńskiej i Średniowiecznej, Wydział Nauk Humanistycznych Katolickiego Uniwersytetu Lubelskiego, adres do korespondencji: Al. Racławickie 14, 20-950 Lublin; e-mail: secretih@kul.pl; ORCID: https:// orcid.org/0000-0001-6024-0127.

${ }^{1}$ Zob. m.in. M. STRASZEWSKA, Życie literackie Wielkiej Emigracji we Francji 1831-1840 (Warszawa: Państwowy Instytut Wydawniczy, 1970), passim; R. JASKUŁA, Karol Forster. Emigracyjny działacz, pisarz i wydawca 1800-1879 (Kraków: Wydawnictwo Naukowe Akademii Pedagogicznej, 2002), 26-94; zob. też syntetyzujące ujęcie S. KALEMBKA, Wielka Emigracja 1831-1863 (Toruń: Wydawnictwo Adam Marszałek, 2003), 73-286.

${ }^{2}$ W 1830 r. ukazało się w Paryżu opracowane na nowo i uzupełnione dzieło Konrada MALTE-Bruna (1775-1826): Tableau de la Pologne ancienne et moderne, contenant la description de ce 
dzieło - jedno z trzech spośród wyżej zasygnalizowanych - La Pologne historique, littéraire, monumentale et pittoresque, zwane w skrócie La Pologne pittoresque, Polska malownicza. Edycja - dwukolumnowa $\mathrm{w}$ formacie in quarto składa się z trzech tomów o objętości ponad 470 stron każdy, wydanych przez Ignacego Stanisława Grabowskiego. Ukazywały się one najpierw w postaci poszytów (livraisons); tom pierwszy w latach 1835-1836; tom drugi - 1837-1838; tom trzeci - 1839-1842 ${ }^{3}$. W każdym woluminie zamieszczono około 60 stalorytowych, całostronicowych ilustracji, prezentujących widoki miast, różne budowle, pomniki i grobowce, sławne postaci, ubiory ludowe oraz sceny historyczne; tomy pierwszy i drugi zawierały mapy (po dwie w każdym z nich). Dzieło zostało dedykowane Francji (Dediée à la France), co wyrażono na frontispisie, znajdującym się w poszczególnych tomach, na którym także zobrazowano braterstwo broni polsko-francuskiej z czasów napoleońskich (podpis głosi: Français et Polonais de tous temps amis) ${ }^{4}$. Zaznaczyć trzeba, że w czasach Ludwika Filipa kult Napoleona rozwijał się bez przeszkód. Król próbował wykorzystać zjawisko dla wsparcia własnego panowania; patronował sprowadzeniu w 1840 r. prochów Cesarza do Paryża. Dochód ze sprzedaży Polski malowniczej

pays [...] (Paris: H. Nicolle et Comp., 1807). Tę nową edycję przygotował w dwóch tomach Leonard Chodźko (późniejszy redaktor La Pologne pittoresque, zob. niżej) przy współpracy Michała Podczaszyńskiego (1800-1835) i Teodora Morawskiego (1797-1879). Wersja ta została wydana także w Brukseli w 1832 r. oraz przetłumaczona na włoski (1830) i niemiecki (1831). Zob. K. EstreICHER, Bibliografia polska XIX stólecia [sic], t. III (Kraków: nakładem Akademii Umiejętności, 1876), 55; t. I (Kraków: nakładem Akademii Umiejętności, 1872), 200; zob. także STRASZEWSKA, Życie literackie, 13-14.

Natomiast w 1832 r. wyszła w Paryżu książka Piotra Pawła Maleszewskiego (1767-1828), którą po jego śmierci opublikowała żona, Essai historique et politique sur la Pologne depuis son origine jusqu'en 1788 (kolejne edycje: Paryż: Fournier, 1833, Berlin: A.M. Schlesinger, 1833). Zob. EstreICHER, Bibliografia polska XIX stólecia, t. III, 51; M. MANTEUfFlowA, „Maleszewski (Maliszewski) Piotr Paweł Jan", w Polski słownik biograficzny, t. XIX, red. E. Rostworowski (Wrocław-Warszawa-Kraków-Gdańsk: Zakład Narodowy im. Ossolińskich, Wydawnictwo Polskiej Akademii Nauk, 1974), 307.

Do dzieł prezentujących - w ograniczonym zakresie - historię Polski można także zaliczyć tłumaczenie na francuski Śpiewów historycznych Niemcewicza, uzupełnionych o rozprawę autorstwa Friedricha Raumera, historyka pruskiego, mówiącą o rozbiorach Polski (w thumaczeniu na francuski; La chute de Pologne). Całość zatytułowana La vieille Pologne. Album historique et poétique, zawierająca 36 litograficznych ilustracji wykonanych przez francuskich grafików, została wydana przez Karola Forstera (zob. niżej), który pozyskał znanych francuskich poetów do dokonania przekładów poszczególnych pieśni. Dzieło wychodziło w poszytach w latach 1833-1836, miało do połowy stulecia cztery wydania we Francji. Zob. zwłaszcza JASKUŁA, Karol Forster, 28-39, 413; A. BANACH, Polska ksiązka ilustrowana 1800-1900 (Kraków: Wydawnictwo Literackie, 1959), 139-141, 419.

${ }^{3}$ Cytowane dalej La Pologne pittoresque.

${ }^{4}$ Por. J. ZIÓŁEK, Studia nad myśla polityczna Wielkiej Emigracji. Napoleon I i Napoleon III (Lublin: Towarzystwo Naukowe KUL, 1995), 59-77. 
przeznaczono na wsparcie Komisji Funduszów Emigracji Polskiej ${ }^{5}$. Całość wychodziła pod nominalną redakcją Towarzystwa Literackiego Polskiego, natomiast głównym redaktorem tomów pierwszego i drugiego był pochodzący z Litwy Leonard Chodźko (1800-1871). Osiadły w Paryżu od 1826 r., dawny student Uniwersytetu Wileńskiego, słuchacz tamże wykładów Lelewela, szybko zasłużył się jako działacz emigracyjny oraz wydawca pamiętników Michała Kleofasa Ogińskiego, Poezji Mickiewicza i autor prac dotyczących m.in. powstań kościuszkowskiego i listopadowego oraz legionów Dąbrowskiego, a także jako dobry geograf i kartograf (sporządził m.in. wyżej wymienione mapy $)^{6}$. Chodźko był również autorem (a właściwie kompilatorem) zasadniczej części tekstów historycznych w pierwszym i drugim tomie Polski malowniczej. Sporo materiału (głównie tłumaczeń prac polskich na francuski) opublikowała tamże jego żona - od 1834 r. - Olimpia z Maleszewskich, urodzona we Francji (1797-1889), bardzo oddana sprawom emigracji ${ }^{7}$. Artykuły o różnej tematyce zamieścili w dziele w jego dwóch tomach Andrzej Słowaczyński, Konstanty Gaszyński, Wojciech Sowiński, Franciszek Ksawery Godebski, Henryk Edward Choński, Krystyn Ostrowski, Feliks Wrotnowski, Juliusz Wysłouch czy Karol Forster - znani w tym czasie (i później) ze swej działalności artystycznej (teatr i muzyka: Słowaczyński, Sowiński, Ostrowski, Forster), literackiej, publicystyczno-historycznej oraz politycznej. Ilustracje tworzyli (czerpiąc z różnych wzorów) wybitni artyści graficy, Antoni Oleszczyński (twórca sceny braterstwa broni, zamieszczonej na frontispisie) oraz Antoni Piliński ${ }^{8}$. Chodźce nie udało się nakłonić Joachima Lelewela, swego dobrego przyjaciela, do napisania artykułu do Polski malowniczej. Historyk był życzliwym, ale i krytycznym odbiorcą dzieła ${ }^{9}$.

\footnotetext{
${ }^{5}$ Szerzej sprawę oświetlają materiały znajdujące się w Bibliotece Polskiej w Paryżu, rkps 1060.

${ }^{6}$ W. BORKOWSKA, „Chodźko Leonard”, w Polski stownik biograficzny, t. III, red. W. Konopczyński (Kraków: Polska Akademia Umiejętności, 1937), 386-388; A. WERNICKI, Leonard Chodźko i jego prace. Krótki rys biograficzny i naukowy (Lwów: Księgarnia Polska, 1880).

${ }^{7}$ M. CZAPSKA, „Chodźkowa Olimpia Ludwika z Maleszewskich”, w Polski słownik biograficzny, t. III, red. W. Konopczyński (Kraków: Polska Akademia Umiejętności, 1937), 389-390. Zob. też STRASZEWSKA, Życie literackie, 288-377; JASKuŁA, Karol Forster, 44.

${ }^{8}$ Biogramy większości wymienionych autorów zamieszczone zostały w Polskim słowniku biograficznym; zob. też Bibliografia literatury polskiej. Nowy Korbut, t. VII-IX, red. I. Śliwińska i in. (Warszawa: Państwowy Instytut Wydawniczy, 1968-1972). Zob. również Z. MARKIEwICZ, T. SIVERT, Melpomena polska na paryskim bruku. Teatralia polskie we Francji w XIX wieku (Warszawa: Państwowe Wydawnictwo Naukowe, 1973), 232-265 (o Krystynie Ostrowskim); STRASZEWSKA, Życie literackie, passim; JASKUŁA, Karol Forster, passim; BANACH, Polska ksią̇ka, passim.

${ }^{9}$ J. Lelewel, Listy emigracyjne Joachima Lelewela, wyd. H. Więckowska, t. I (Kraków: Polska Akademia Umiejętności, 1948), 370, 375-376, 377-379, 381-382; t. II (Kraków: Polska Akademia Umiejętności, 1949), 15, 84-85, 87, 113-114, 165-166, 222, 227.
} 
$\mathrm{Na}$ skutek zatargu na tle finansowym, do którego doszło 2 marca $1838 \mathrm{r}$. pomiędzy Chodźką a jego współpracownikiem Henrykiem Chońskim (1809-1881), Chodźko zrezygnował z redagowania kolejnego tomu Polski malowniczej (choć już przygotował materiały do trzeciego tomu dzieła). Zatarg, dodajmy, który omal nie zakończył się pojedynkiem i miał sądowe reperkusje, był niejako kontynuowany - i dokumentowany - m.in. poprzez szereg druków ulotnych publikowanych przez adwersarzy. Wywoływał i pogłębiał nieprzychylne Chodźce reakcje ze strony wydawcy (J.S. Grabowskiego) i części autorów piszących do Polski malowniczej - a szerzej wśród ogółu emigrantów, co, by tak rzec, zagęszczało atmosferę zacietrzewienia i kłótliwości dającą się odczuć $\mathrm{w}$ ich środowisku ${ }^{10}$. Redagowanie tomu trzeciego dzieła przejął Choński ${ }^{11}$. Wśród autorów znalazł się Ludwik Mierosławski, cieszący się już wówczas uznaniem ze względu na swą pracę o przebiegu powstania listopadowego, napisaną w języku francuskim ${ }^{12}$. Opracował on główną część historyczną tegoż tomu, przedstawiającą wydarzenia od śmierci Jana III Sobieskiego do czasów współczesnych ${ }^{13}$. W tekście ujawnia się dążność autora do uchwycenia istotnych cech omawianych wydarzeń. Mierosławski nie rezygnując z plastyczności opisu, daje syntetyzujący obraz dziejów Rzeczypospolitej, zwraca zwłaszcza uwagę na działalność głównych grup (,partii” politycznych); „w rozprawie tej bardzo wyraźnie rysuje się wpływ J. Lelewela, szczególnie koncepcji 'demokracji szlacheckiej', która przez odejście od ludu i zgniecenie wolności zgubiła Polskę, będąc wiedziona przez arystokrację. W swych rozważaniach reprezentuje Mierosławski stanowisko profrancuskie i zdecydowanie antysaskie"14. Chodźko, mimo odstąpienia od dalszego

\footnotetext{
${ }^{10}$ Chodźko ukazał ze swego punktu widzenia przebieg najbardziej gorącej fazy sporu w druku ulotnym datowanym 24 maja 1838 r. (w Paryżu), zawierającym tekst dwukolumnowy - polski i francuski (Polska malownicza. Dnia 20 maja 1838 podobato się P. J. S. Grabowskiemu [...]). O przebiegu zatargu zob. M. ŻYCHOwSKI, Ludwik Mierosławski 1814-1878 (Warszawa: Państwowe Wydawnictwo Naukowe, 1963), 143 i przypisy 8-10 tamże; STRASZEWSKA, Życie literackie, 288, 420-422 (tu z odesłaniem do podstawy źródłowej); JASKUŁA, Karol Forster, 44, 71-72. Zob. też S. GŁĄBIŃSKI, „Choński Henryk”, w Polski stownik biograficzny, t. III, red. W. Konopczyński (Kraków: Polska Akademia Umiejętności, 1937), 419. Por. KALEMBKA, Wielka Emigracja, 248-254.

${ }^{11}$ GŁĄBIŃSKI, „Choński Henryk”, 419.

${ }^{12}$ Histoire de la révolution de Pologne [...], t. I-III, Paris 1836-1838; druga edycja ukazała się w Paryżu w 1838 r. Zob. EstreICHER, Bibliografia polska XIX stólecia, t. III, 124; ŻYCHOWSKI, Ludwik Mierosławski, 124-140; S. KIENIEwICZ, „Mierosławski Ludwik”, w Polski słownik biograficzny, t. XX, red. E. Rostworowski (Wrocław-Warszawa-Kraków-Gdańsk: Zakład Narodowy im. Ossolińskich, Wydawnictwo Polskiej Akademii Nauk, 1975), 812.

${ }^{13}$ ŻYCHOWSKI, Ludwik Mierosławski, 142-144; zob. też tamże o wstąpieniu Mierosławskiego do Towarzystwa Literackiego Polskiego w 1838 r., 145-148; KIENIEwICZ, „Mierosławski Ludwik”, 812.

${ }^{14}$ ŻyCHOwsKI, Ludwik Mierosławski, 144.
} 
redagowania Polski malowniczej, nie zrezygnował jednak ze swego rodzaju kontynuacji przedsięwzięcia. W latach 1839-1841 zredagował bowiem - i w dużej części sam napisał - dzieło La Pologne illustrée, Polska ozdobnicza, które wychodziło w Paryżu w 58 poszytach, mając ten sam format i podobną liczbę stron, co tomy Polski malowniczej, choć mniejszą liczbę ilustracji (było ich 44) ${ }^{15}$. Materiał historyczny (podany w jednej spójnej części - nie rozbijanej wstawkami - zajmującej pierwszą połowę tomu) obejmował taki okres, jak w trzecim tomie Polski malowniczej ${ }^{16}$. Autorami tekstów byli, prócz Chodźki, jego żona Olimpia (tłumaczenia na francuski prac literackich i wspomnieniowych), Albert Sowiński (wiadomości o teatrze) i Feliks Wrotnowski (dawne wierzenia na Litwie). Joachim Lelewel przysłał swój artykuł z zakresu numizmatyki polskiej, opatrując go notami i dwiema wykonanymi przez siebie tablicami (staloryty) ${ }^{17}$.

W okresie gdy wychodziły poszyty tomu trzeciego Polski malowniczej oraz poszyty Polski ozdobniczej, ukazała się kolejna publikacja - trzecia spośród wyżej wspomnianych - przedstawiająca Polskę/Rzeczpospolitą francuskojęzycznym czytelnikom. Autorem (kompilatorem) był rówieśnik i znajomy Chodźki, Karol Forster (1800-1879), który zamieścił swe teksty (o teatrze w Polsce i o klasztorach w podkrakowskich oraz w podwarszawskich Bielanach) w trzecim tomie Polski malowniczej. Forster urodzony w Warszawie w rodzinie luterańskiej, aktywny uczestnik życia kulturalnego stolicy (zwłaszcza teatralnego i muzycznego), służył w sztabach armii powstańczej i opuścił w stopniu majora - kraj w październiku 1831, a w grudniu następnego roku osiadł w Paryżu ${ }^{18}$. Zamierzył, podobnie jak Chodźko, propagować historię

\footnotetext{
${ }^{15}$ Cytowane dalej La Pologne illustrée.

${ }^{16}$ Nie należy jednak traktować Polski ozdobniczej jako tomu czwartego Polski malowniczej, występującego pod zmodyfikowanym tytułem - tak BANACH, Polska ksiażka, 151.

17 „Numismatique polonaise. Notice sur la monnaie de Pologne”; La Pologne illustrée, 458-472. Jest to ostatni artykuł w dziele, zawarty w 58 poszycie (w poszycie 57 ukazała się tablica z wizerunkiem Lelewela, opatrzonym informacjami biograficznymi). Zob. LELEWEL, Listy, t. II, 323, 372-377, 380, 383-384, 387. Zob. H. MERZBACH, Prace numizmatyczne Joachima Lelewela w Belgii (Kraków: nakładem Towarzystwa Numizmatycznego, 1889) (odbitka z „Wiadomości Numizmatyczno-Archeologicznych").

${ }^{18}$ Karol Forster służył w wojsku Królestwa w latach 1816-1817, a więc jeszcze za czasów wielkiego księcia Konstantego. Następnie porzucił armię i usiłował zrobić karierę w administracji cywilnej. Mieszkając w Warszawie, pisywał recenzje teatralne i przekładał z francuskiego sztuki sceniczne, prowadził rodzaj salonu muzycznego w swym mieszkaniu. Po wybuchu powstania ponownie wstąpił do wojska w styczniu $1831 \mathrm{r}$. W trakcie swojej pracy sztabowej był szczególnie związany z gen. Janem Krukowieckim. W pierwszym roku pobytu na wychodźstwie sześć miesięcy spędził w Dreźnie. W Paryżu przebywał od grudnia 1832 do sierpnia 1849 r., po czym osiadł w Berlinie. W 1848 r. związał się z Hotelem Lambert i odbywał (zwłaszcza w latach
} 
i kulturę polską. Już w początkowych latach pobytu w stolicy Francji zdołał wydać we francuskim tłumaczeniu, w eleganckiej szacie typograficznej z kilkudziesięcioma litografiami, Śpiewy historyczne Niemcewicza ${ }^{19}$. Natomiast w 1840 r. opublikował - również w Paryżu - dzieło Pologne. Ukazało się jako dziesiąty tom w podserii opisów krajów Europy (w sumie wyszło 40 tomów w tej podserii) będącej częścią składową serii L'Univers pittoresque, prezentującej w osobnych woluminach poszczególne kraje i regiony świata z podziałem na kontynenty $^{20}$. L'Univers pittoresque, wydawany (i drukowany) przez zasłużoną, od dawna działającą firmę Didot - $\mathrm{w}$ tym przypadku Firmin Didot Frères (czyli bracia Firmin i Pierre) - niejako uosabiał wysoką jakość typograficzną, charakterystyczną dla druków tej oficyny. Forstera Pologne była publikowana $\mathrm{w}$ poszytach $\mathrm{w}$ formacie in octavo (jak inne tomy wspomnianej serii). Liczy prawie 350 stron (druk dwukolumnowy) i zawiera 55 całostronicowych stalorytów (łącznie z mapą ukazującą granice rozbiorów). Ilustracje po części wzorowane na tych, które ozdabiają Polskę malownicza, zostały wykonane przez francuskich rysowników i rytowników ${ }^{21}$.

Wspomniane dzieła zyskały dużą poczytność i do końca XIX stulecia miały po kilka wydań, zostały także przetłumaczone na kilka języków i opublikowane również w innych poza Francją krajach europejskich, znane były m.in. w Stanach Zjednoczonych ${ }^{22}$. Warto przy tym przytoczyć uwagę Marii Straszewskiej o tym, że Polska malownicza „obecnie jest bodaj najczęściej spotykanym $z$ zachowanych w bibliotekach francuskich wydawnictw o Polsce z epoki romantyzmu"23. Dzieła te miały stanowić syntetyzujące ujęcie spraw polskich, ukazując przy tym ich specyfikę i - niekiedy - wyjątkowość, a także zaznaczając ich usytuowanie w kontekście słowiańskim. Powstałe jako swoiste świadectwo tragicznego okresu dziejów Rzeczypospolitej, miały być atrakcyjne

1848-1849, 1855) podróże do kilku krajów, wypełniając misje w ramach projektów politycznych ks. Adama Czartoryskiego. Zmarł w Berlinie. Zob. M. TYrowicz, „Forster Karol”, w Polski stownik biograficzny, t. VII, red. W. Konopczyński (Kraków: Polska Akademia Umiejętności, Polska Akademia Nauk, Wydawnictwo Zakładu Narodowego im. Ossolińskich, 1948-1958), 67-69; JASKUŁA, Karol Forster, 10-25, 79-296.

${ }^{19}$ Zob. wyżej przypis 2.

${ }^{20}$ JASKUŁA, Karol Forster, 39-40.

${ }^{21}$ Cytowane dalej Pologne.

${ }^{22}$ STRASZEWSKa, Życie literackie, 287-289; JASKUŁA, Karol Forster, 40-42.

${ }^{23}$ STRASZEWSKA, Życie literackie, 288. Dodać warto, że Pierre Francastel, jeden z najbardziej znanych historyków i socjologów sztuki, będąc w latach trzydziestych XX stulecia wicedyrektorem Instytutu Francuskiego w Warszawie, opublikował w 1934 r. w Grenoble popularną w swoim czasie, bogato ilustrowaną książkę - informator o Polsce i nadał jej tytuł La Pologne pittoresque, nawiązujący do tytułu i jakości edytorskiej omawianego w niniejszym artykule dzieła. 
dla odbiorcy francuskiego i niejako na podłożu zrozumienia przez niego i docenienia uwarunkowań historii i kultury (jak również religijności) polskiej, miały wzbudzać - czy pogłębiać - w odbiorcy sympatię (podziw) dla postawy patriotycznej Polaków oraz ich dążeń niepodległościowych. Miały też pobudzać nieprzyjaciół Polski do refleksji nad jej losem - w duchu sprawiedliwości i wspaniałomyślności. Miały podkreślać wzajemne związki Polski i Francji oraz wspólną obywatelom tych krajów potrzebę wolności ${ }^{24}$. Miały wreszcie być wyrazem umiłowania Ojczyzny, która im bardziej jest nieszczęsna, tym bardziej zasługuje na oddanie i miłość swych dzieci: „Plus la Pologne est malhereuse, plus ses enfants lui doivent de dévouement et d'amour" ${ }^{25}$.

Podstawą prezentacji spraw polskich $\mathrm{w}$ wymienionych publikacjach jest narracja historyczna, czerpiąca m.in. z dzieł Naruszewicza (Historya narodu polskiego), Niemcewicza (Zbiór pamiętników historycznych o dawnej Polszcze) czy Lelewela. W Polsce malowniczej i w Polsce ozdobniczej tok tej narracji jest niejako inkrustowany (można też rzec przerywany) wstawkami ukazującymi zagadnienia szczegółowe o charakterze wspomnieniowo-historycznym, biograficznym, geograficznym, kulturowym czy religijnym, ujętymi w formie mniej lub bardziej obszernych artykułów, jak i w formie ilustracji. Wstawki, przygotowane, jak wiadomo, przez różnych autorów, nie łączą się chronologicznie z porządkiem wywodu historycznego. W Forstera Polsce zagadnienia tego rodzaju mieszczą się przed i po głównej narracji historycznej (nie jest ona przerywana wstawkami); po niej następuje jeszcze omówienie wydarzeń z okresu porozbiorowego. Tak różnorodny materiał prezentowany w poszytach składających się na każde ze wspomnianych dzieł został po zamknięciu danego tomu uporządkowany tematycznie w dołączonym do niego spisie treści. W trzech tomach Polski malowniczej, jak i w Polsce ozdobniczej wydzielono podobny zestaw tematów ${ }^{26}$. W pracy Forstera (Pologne)

${ }^{24}$ La Pologne pittoresque, t. I, Prospectus; Introduction, 1-4; La Pologne illustrée, 1-11; ForsTER, Pologne, 1-5.

${ }^{25}$ La Pologne illustrée, 2.

${ }^{26} \mathrm{~W}$ tomie pierwszym La Pologne pittoresque wydzielono tematy: Histoire; Souvenirs historiques; Monuments; Villes; Sittes pittoresques, châteaux, palais, édifices, églises, monastères; Curiosités naturelles; Cultes religieux; Cérémonies civiles et militaries; Costumes. Usages; Coutumes, peinture de moeurs et cérémonies des anciens châteaux; Contes, légendes, traditions populaires; Biographie; Musique. Danses; Poésie. W tomie drugim ten zestaw został uzupełniony o działy: Établissement scientifiques (tu omówiono Liceum Krzemienieckie) i Finances (z jednym artykułem: Banque de Pologne). W tomie trzecim wydzielono następujące tematy: Histoire; Souvenirs historiques; Statistique. Géographie; Littérature. Législation; Sites pittoresques, châteaux, palais, édifices, églises, monastères, tombeaux; Légendes. Nouvelles; Cultes religieux; Théâtre; Curiosités naturelles; Biographies (dział rozbudowany - 15 sylwetek). La Pologne illustrée zawiera działy: Histoire; Souvenirs historiques; Événements contemporains (o Rzeczypospolitej Krakowskiej); Mémoires (wspomnienia 
tematyka „pozahistoryczna” została zebrana w trzech głównych działach o nierównomiernym zestawie zagadnieńn ${ }^{27}$. Narrację historyczną - narrację „przewodnią" w omawianych publikacjach Chodźko i Forster przedstawili według podziału: La Pologne conquérante (860-1139), Polska podbijająca; La Pologne en partage (1139-1333), Polska w podziałach; La Pologne florissante (13331587/1588), Polska kwitnąca; La décadence de la Pologne (1587/1588-1795), Polska upadająca. Wydzielony został także okres historii współczesnej - porozbiorowej (La Pologne renaissante; Polska odradzająca się). W pierwszym tomie Polski malowniczej wskazano ponadto na okres „bajeczny”: Traditions fabuleuses (550-860). Podział ma odzwierciedlenie w rozłożeniu narracji historycznej w poszczególnych tomach Polski malowniczej (w tomie pierwszym przedstawiono czas „bajeczny” oraz dwa kolejne okresy - do 1333; w tomie drugim omówiono okres Polski kwitnącej i część okresu Polski upadającej - do śmierci Jana III; w tomie trzecim zawarto drugą część tegoż okresu oraz okres Polski odradzającej się, doprowadzony do 1830). Materiał historyczny w Polsce ozdobniczej kończy się na wspomnieniu powstania listopadowego. Forster wieńczy swe dzieło omówieniem okresu 1795-1840 (La Pologne renaissante, XIX siècle; Révolution nationale, 1830-1831; La Pologne, province russe, 1831-1840). Zastosowana periodyzacja zgodna jest z ujęciem zaproponowanym i uzasadnionym niegdyś przez Lelewela ${ }^{28}$. Chociaż Chodźko był zwolennikiem (by nie powiedzieć entuzjastą) koncepcji historiograficznych oraz społeczno-politycznych Lelewela, podobnie jak część autorów artykułów zamieszczonych w Polsce malowniczej (wśród tych autorów zwraca uwagę Franciszek Ksawery Godebski) ${ }^{29}$, to historyk wskazywał, że jego przyjaciel niezbyt fortunnie ujmuje historię Polski/Rzeczypospolitej w dziele, które realizuje. Raził go zwłaszcza charakter „rojalistowsko-arystokratyczny” prezentowanej tematyki, to, że jest ona głównie o „królach i panach" ${ }^{30}$. W tym monarchistycznym, jak oceniał, ujęciu historii niejako

gen. Józefa Kopcia); Numismatique; Littérature et Civilisation; Mythologie (o wierzeniach dawnych Litwinów); Monuments; Marine; Voyages (o podróżach Jakuba Sobieskiego); Sites pittoresques, châteaux, palais, édifices, églises, monastères; Contes, légendes, nouvelles; Biographie; Théâtre; Danses.

${ }^{27}$ Partia wstępna dzieła, poprzedzająca prezentację historyczną zawiera informacje z zakresu geografii, demografii, elementów ustrojowych, handlu i religii (Forster, Pologne, 1-43). Po części historycznej następują działy: Moeurs et contumes (tu 32 zagadnienia szczegółowe) oraz Civilisation (tu zagadnienia: Sciences et lettres; Musique, Théâtre).

${ }^{28}$ La Pologne pittoresque, t. I, 9; M. WIERZBICKA, Dawne syntezy dziejów Polski. Rozwój i przemiany koncepcji metodologicznych [seria: Monografie z Dziejów Nauki i Techniki, t. XCV] (Wrocław: Zakład Narodowy im. Ossolińskich, 1974), 24-27.

${ }^{29}$ A.F. GRABSKI, Troski i nadzieje. Z dziejów polskiej myśli społecznej i politycznej XIX wieku (Łódź: Wydawnictwo Łódzkie, 1981), 68-74.

${ }^{30}$ LeLEWEL, Listy, t. II, 15. 
gubiła się tak ważna dla Lelewela idea gminowładztwa ${ }^{31}$. Dodajmy, że „Samotnik brukselski" wytykał Chodźce błędy w omawianiu zagadnień z historii średniowiecznej, w tym dotyczących Kościoła w Polsce ${ }^{32}$. Zaznaczał niedokładności i zmyślenia $\mathrm{w}$ materiale ilustracyjnym ${ }^{33}$. Z uznaniem wyrażał się natomiast o mapach zamieszczonych w La Pologne pittoresque ${ }^{34}$. Winszował przy tym przyjacielowi sukcesów wydawniczych ${ }^{35}$. Dodajmy, że bliskie historiograficznej myśli Lelewela było umieszczenie w Polsce malowniczej (a także w Polsce ozdobniczej) narracji historycznej w towarzystwie zagadnień geograficzno-krajoznawczo-etnograficznych.

W panoramie spraw i ,rzeczy” polskich (polsko-litewsko-ruskich) ukazanej w omawianych dziełach ważną, choć raczej nie eksponowaną rolę, odgrywa tematyka religijna, zwłaszcza dotycząca Kościoła katolickiego. W Polsce malowniczej i w Polsce ozdobniczej jest prezentowana w kilku ujęciach. Najpierw w głównej narracji historycznej, jako część historii państwa, kształtująca niektóre (niekiedy zasadnicze) aspekty jej biegu. Drugie ujęcie zostało ukazane w tekstach prezentujących najważniejsze świątynie i klasztory w Polsce/Rzeczypospolitej (także protestanckie) oraz duchowieństwo sprawujące w nich służbę Bożą ${ }^{36}$; budowle sakralne są oczywiście wspomniane w artykułach opisujących miasta. W La Pologne pittoresque ponadto znajdują się niezbyt obszerne ujęcia kilku innych zagadnień z zakresu historii Kościoła i religijności. Zamieszczono zatem krótki rys biograficzny (informujący o biskupie krakowskim Samuelu Maciejowskim, kanclerzu wielkim koronnym, żyjącym w latach 1499-1550) ${ }^{37}$. Krótki jest również artykuł omawiający

\footnotetext{
${ }^{31}$ Por. GraBSKI, Troski, 73; A.F. GRABSKI, Zarys historii historiografii polskiej (Poznań: Wydawnictwo Poznańskie, 2003), 120. Zob. też F. BRONOwsKI, Idea gminowładztwa w polskiej historiografii. Geneza i formowanie się syntezy republikańskiej J. Lelewela (Łódź-Wrocław: Zakład Narodowy im. Ossolińskich, 1969).

${ }^{32}$ LeLEWEL, Listy, t. I, 370, 375, 378-379, 381-382.

${ }^{33}$ LELEWEL, Listy, t. I, 376; t. II, 15, 165-166, 227.

${ }^{34}$ LELEWEL, Listy, t. I, 376; t. II, 227.

${ }^{35}$ LELEWEL, Listy, t. I, 336; t. III, 25.

${ }^{36}$ Kolejność według spisu treści zagadnień: La Pologne pittoresque, t. I, 192-196: Église cathédrale de Cracovie; 137-140: Ermitage de Sainte Salomée à Grodzisko; 105-106: Monastère de Tyniec; 464-468: Église et abbaye de Sainte-Croix à Lysa-Gora; 216-220: Église et monastère de Czenstochowa; t. II, 191-193: Le mont Calvarie et le château de Lanckorona; 129-131: Église cathèdrale de Wilna; t. III, 149-158: Le monastère de Biélany; 471-472: L'église de SaintFrançois-d'Assise à Krakovie; 89-96: Le clergé catholique; église cathédrale de Gnèzne. La Pologne illustrée, 300: Couvent et Église de Tyniec, dans l'ancien palatinat de Krakovie; 280: Église evangelique à Warsovie; 401-402: Église de Saint-Stanislas à Malatycze.

${ }^{37}$ La Pologne pittoresque, t. III, 459-460: Samuel Macieiowski (z artystycznie wykonanym stalorytem przedstawiającym płytę nagrobną tego biskupa; tablica między stronami 458 a 459). Zob. niżej przypis 42 .
} 
śpiewy i muzykę kościelną (także protestancką), prezentowaną w szerszym kontekście muzyki i śpiewów świeckich z uwzględnieniem muzyki tanecznej ${ }^{38}$. Dość pobieżnie zostały potraktowane w tym dziele obrzędy i zwyczaje religijne; wzmiankowane są jedynie te, które odnoszą się do wydarzeń związanych $\mathrm{z}$ panowaniem władców ${ }^{39}$. Jedynie dwa artykuły omawiają zagadnienia z historii stosunków między Kościołem katolickim a państwem oraz stosunków między tymże Kościołem a wyznaniami reformowanymi ${ }^{40}$. W Polsce ozdobniczej opublikowano artykuł (autorstwa Feliksa Wrotnowskiego) dotyczący wierzeń przedchrześcijańskich na Litwie ${ }^{41}$. O wierzeniach pogańskich czytamy także w dziele Forstera, w akapicie mieszczącym się przy końcu szeregu informacji o Polsce/Rzeczypospolitej, wprowadzających do lektury części mówiącej o historii. Krótkie przedstawienie tych wierzeń (w Polsce i na Litwie) stanowi swego rodzaju wstęp do ukazania obecności chrześcijaństwa, ze stosunkowo wyraźnym uwzględnieniem niektórych herezji oraz protestantyzmu. Autor podkreśla przy tym tolerancję religijną panującą w Rzeczypospolitej ${ }^{42}$. Kilka zagadnień dotyczących ceremonii i obyczajów o charakterze religijnym, a także zabobonów, mieści się w dziale następującym po części historycznej dzieła ${ }^{43}$.

Wspomniane wyżej treści są w omawianych dziełach niejako dopełnione przez całostronicowe ilustracje. W tomie pierwszym i drugim Polski malow-

${ }^{38}$ La Pologne pittoresque, t. I, 329-336, 425-432: Coup d'oeil historique sur la musique religieuse et populaire et sur les danses en Pologne. W tomie drugim zamieszczono ciąg dalszy tego artykułu, autorstwa Wojciecha (Alberta) Sowińskiego, dotyczy on jednak muzyki tanecznej i śpiewów ludowych na różnych obszarach Rzeczypospolitej (t. II, 241-248, 417-424). W tomie pierwszym początkowa partia tekstu Sowińskiego zawiera informacje o dawnych śpiewach religijnych (m.in. o pieśni Bogurodzica i o autorstwie pieśni; t. I, 329-330).

${ }^{39}$ La Pologne pittoresque, t. I, 238-240: Élection et couronnement des rois de Pologne; t. II, 276-280: Funérailles des rois de Pologne, des grands-ducs de Litvanie et des seigneurs.

${ }^{40}$ La Pologne pittoresque, t. I, 404-408: De l'infuence de l'Eglise romaine et de la Sainte Inquisition en Pologne; t. II, 304-310: Coup d'oeil historique sur la réforme en Pologne (ten tekst dotyczący reformacji, zaanonsowany w spisie treści, jest jednak fragmentem prezentacji panowania Zygmunta III).

${ }^{41}$ La Pologne illustrée, 404-416: Esquisse sur la réligion païenne, sur les traditions populaires et sur les anciens usages des Litvaniens.

${ }^{42}$ Forster, Pologne, 39-43.

${ }^{43} \mathrm{~W}$ dziale Moeurs et coutumes przedstawiono m.in. ceremonie religijne związane $\mathrm{z}$ namaszczeniem i koronację królewską (ForSTER, Pologne, 172-175: Sacre et couronnement) oraz obrzędami pogrzebowymi króla (180-182: Funérailles royales) i szlachty (222-223: Obsèques des nobles). Zostały przedstawione zwyczajowe obchody Wielkiego Tygodnia (223-225: Semaine sainte). Forster omówił także ludowe obyczaje towarzyszące śmierci, a wywodzące się z dawnych wierzeń słowiańskich (250-251: Cérémonies funèbres; 251-252: Fête des morts; dziady). Obszerniej zostały przedstawione zabobony (246-250: Superstitions). 
niczej obrazują one świątynie i klasztory katolickie, w tym znane sanktuaria. Umieszczono również widok kościoła protestanckiego (w Warszawie). Ukazano ponadto $\mathrm{w}$ tomie pierwszym przyjęcie chrześcijaństwa przez Mieszka, a także podkreślono religijny charakter ceremonii koronacji królewskiej Mendoga; zaznaczmy, że w tym tomie zobrazowano też koronację królewską Bolesława Chrobrego - Bolesław stojąc, sam sobie nakłada koronę o charakterystycznym kształcie, po lewej stronie władcy siedzi biskup, gestem prawej dłoni złożonej na szatach pontyfikalnych wyrażający cześć dla króla ${ }^{44}$. Tom trzeci wyróżnia się tym, że oprócz widoków kościołów zawiera wizerunki duchownych katolickich zasłużonych w dziejach Rzeczypospolitej, głównie w XVIII stuleciu (w sumie osiem wizerunków) ${ }^{45}$. Około jednej dziesiątej części materiału ilustracyjnego Polski malowniczej odnosi się do szeroko rozumianej tematyki kościelnej. W Polsce ozdobniczej (ukazującej, przypomnijmy, historię współczesną) tego rodzaju tematyka jest reprezentowana bardzo skąpo w zestawie ilustracji. W dziele zamieszczono trzy widoki świątyń, przy czym dwie świątynie (ewangelicka w Warszawie i katolicka w Malatyczach) zostały wzniesione w ostatniej ćwierci XVIII w. (a więc w czasach „współczesnych”); znajdujemy także wizerunek biskupa Adama Naruszewicza, z podkreśleniem, że był polskim historykiem i poe$\mathrm{tą}^{46}$. Forster dał również bardzo niewiele ilustracji o tej tematyce. Pologne zawiera trzy staloryty przedstawiające dwie świątynie katolickie: katedrę wawelską wewnątrz oraz kościół (i klasztor) jasnogórski (widok wzorowany na ilustracji zamieszczonej w tomie pierwszym Polski malowniczej).

${ }^{44} \mathrm{~W}$ tomie pierwszym Polski malowniczej ilustracje przedstawiają kolejno: Mieszka wprowadzającego chrześcijaństwo w Polsce, klasztor w Tyńcu, pustelnię św. Salomei w Grodzisku (na Grodzisku) pod Krakowem, katedrę wawelską, kościół i klasztor w Częstochowie, koronację Mendoga, kościół w Kochawinie, kościół św. Krzyża na Łysej Górze. W tomie drugim zobrazowano: katedrę w Wilnie, świątynię na Górze Kalwarii, kościół bernardynów w Warszawie.

${ }^{45} \mathrm{~W}$ tomie trzecim znajdujemy ilustracje ukazujące: katedrę w Gnieźnie, kościół protestancki (ewangelicki) w Warszawie, Stanisława Konarskiego, biskupa Andrzeja Załuskiego, klasztor kamedułów pod Krakowem (na Bielanach), biskupa Ignacego Krasickiego, biskupa krakowskiego Kajetana Sołtyka (staloryt przedstawia symbolicznie scenę jego zesłania na Sybir), kościół parafialny w Żółkwi, Hugona Kołłątaja, nagrobek biskupa Samuela Maciejowskiego, księdza Adama Logę na czele grupy powstańców listopadowych, kościół franciszkanów w Krakowie.

${ }^{46}$ W La Pologne illustrée zobrazowano kolejno: kościół ewangelicki w Warszawie (rytował Adam Piliński; widok tego kościoła znacznie mniejszej wartości artystycznej mieści się w tomie trzecim Polski malowniczej - zob. przypis powyżej); kościół i klasztor tyniecki (ukazany tu z szerszej i bardziej, by tak rzec, romantycznej perspektywy niż w tomie pierwszym Polski malowniczej); kościół św. Stanisława w Malatyczach, w dekanacie Orsza w diecezji wileńskiej (został wzniesiony na wzór bazyliki św. Piotra w Rzymie, co staloryt wyraźnie obrazuje: poświęcenie tego kościoła dominikańskiego - odbyło się w 1794 r., jak informuje napis na ilustracji); Adama Naruszewicza. 
Obecność tematyki religijnej w artykułach zamieszczonych poza główną narracją historyczną, jak i na ilustracjach, niejako jest zbieżna (choć chyba nie w pełni) z myślą Chodźki co do znaczenia religii w historii Polski, wyrażoną przez niego we wstępie do Polski malowniczej. Chrześcijaństwo, zaprowadzane za czasów Mieszka, wyraźnie zmieniło „oblicze” kraju, którym władali jego następcy. Przyniosło nowe obyczaje i cywilizację i stało się impulsem rozwoju Polski ${ }^{47}$. Władza w państwie - w państwie polskim czerpie uzasadnienie swego istnienia i swych prerogatyw z religii (religii chrześcijańskiej, w domyśle - katolickiej). Religia tworzy, by się tak wyrazić, szlachetnego człowieka i dobrego obywatela. Jednoczy obywateli i jest źródłem zgody między nimi. Stąd też, gdy obywatele nie postępują ściśle w zgodzie $\mathrm{z}$ nakazami ewangelicznymi, ich państwo nie uniknie upadku: „,nous ne pouvons donc éviter notre ruine si nous ne suivons exactement l'evangile que nous devons observer" ${ }^{\text {"48 }}$. Szczególna rola w rozszerzaniu Ewangelii - i szczególna rola w państwie polskim, w Rzeczypospolitej („dans notre république") - przypada duchowieństwu. Duchowni powinni pociągać ogół obywateli swym przykładem życia ewangelicznego - życia w ubóstwie i pokorze, tak jak w czasach apostolskich. Kult boży winien być sprawowany w jednakiej formie, bez ostentacyjności, zarówno w najmniejszej parafii, jak i w kościołach katedralnych. Do osłabienia ducha ewangelicznego wśród duchowieństwa przyczyniły się z czasem, jak sądzi Chodźko, donacje przyznawane Kościołowi przez władców i możnych ${ }^{49}$. Forster podkreśla również znaczenie religii katolickiej najpierw w państwie polskim, a później w polsko-litewskim. Stosunkowo obszernie przedstawia przy tym wierzenia przedchrześcijańskie w Polsce, na Rusi i na Litwie, a także na ziemiach Prusów, co uwydatnia, że nawet w czasach pogańskich istniał w tych krajach bogaty, zróżnicowany zespół wierzeń i mitów (zapewne przyciągający swą egzotyką uwagę francuskiego czytelnika). Mimo że religia katolicka miała w Polsce/ Rzeczypospolitej status religii panującej, niejako państwowej, to inne wyznania były tolerowane i cieszyły się ochroną (Forster przywołuje w tym kontekście konfederację warszawską z 1573 r.). Kościół w Polsce (hierarchia kościelna) wykazywał, tak jak w innych krajach słowiańskich, sporą niezależność wobec Stolicy Apostolskiej w sprawach, które można określić jako dyscyplinarne. Ważną przemianę $\mathrm{w}$ obrazie wyznaniowym przyniósł protestantyzm, mogący rozwijać się w Polsce w atmosferze panującej w niej

${ }^{47}$ La Pologne pittoresque, t. I, 1-2.

${ }^{48}$ La Pologne illustrée, 11.

${ }^{49}$ La Pologne illustrée, 11-12. 
wolności ${ }^{50}$. Autor, wyznający luteranizm, nieprzypadkowo uwydatnia ten aspekt „charakteru” swej Ojczyzny. Wyraźnie przy tym wskazuje na budującą postawę duchowieństwa, zwłaszcza w trudnych dla niej czasach. Umiłowanie Boga i umiłowanie Ojczyzny są bowiem, jak dodaje, nierozłączne w życiu polskiego kleru ${ }^{51}$.

Chodźko i Forster uważają zatem, że „charakter” i historia Polski/Rzeczypospolitej były - i są - wyraźnie związane z Kościołem, z ideałami życia, które wyznaje i propaguje. Obydwaj wskazują na „pożądane” cechy, jakimi winien odznaczać się polski Kościół, aby tym bardziej być „przewodnikiem” w tej historii. Według Chodźki jest to wymóg dążenia do prostoty i ubóstwa życia Kościoła w czasach apostolskich. Natomiast dla Forstera istotne jest zachowywanie wolności, co wyrażać się winno - tak jak i dotychczas w tolerancji wobec innych wyznań oraz, by tak rzec, w asertywnej postawie wobec Rzymu. Pogląd Forstera na stosunek Kościoła polskiego do Stolicy Apostolskiej jest zbliżony, jak można zauważyć, do gallikanizmu.

Obecność Kościoła w historii Polski/Rzeczypospolitej, obecność kształtująca tę historię, została ukazana w kilku odsłonach w głównej narracji zawartej $\mathrm{w}$ omawianych dziełach. Wydarzeniami niejako inaugurującymi ową obecność był oczywiście chrzest Mieszka (Mieczysława I, Mieczyslas ${ }^{\mathrm{er}}$ ), a później, w odniesieniu do Litwy, „epizodyczny” chrzest Mendoga oraz zwłaszcza wprowadzenie chrześcijaństwa do tego kraju w czasach panowania Jagiełły $^{52}$. Chrześcijaństwo nie zostało zaszczepione na „pustyni religijnej”. Zarówno Chodźko, jak i Forster rysują, jak wspomniano, obraz wierzeń przedchrześcijańskich w Polsce i na Litwie, zaznaczając, że nie zanikły one całkowicie i pewne ich pozostałości, niekiedy dosyć żywotne, egzystujące w mniejszym czy większym stopniu razem z obyczajowością chrześcijańską, można napotkać i w czasach obecnych (to znaczy w I połowie XIX w.). Wedle La Pologne pittoresque czasy przedmieszkowe - ukazane w świetle „podań bajecznych" (traditions fabuleuses) zaczerpniętych z Długoszowych Roczników - charakteryzowały się bałwochwalstwem, będącym mieszaniną wierzeń greckich, rzymskich i saksońskich. Chodźko przyjął zatem, w ślad za Naruszewicza Historya narodu polskiego (t. I), ową „interpretatio Graeco-Romana” (et Germana), jako właściwą perspektywę prezentacji tego zagadnienia ${ }^{53}$. Takie

\footnotetext{
50 „L'élement naturel, inséparable de la Pologne, c'était la liberté, et Rome lançait en vain des lois qui punissaient d'exil ou de mort toute croyance nouvelle"; FOrSTER, Pologne, 42.

${ }^{51}$ Forster, Pologne, 39-43.

${ }^{52}$ La Pologne pittoresque, t. I, 1, 15; t. II, 57, 59; Forster, Pologne, 46, 65, 79.

${ }^{53}$ La Pologne pittoresque, t. I, 15. Por. M. Michalski, Dawni Stowianie w tradycji polskiej I połowy XIX w. (Poznań: Wydawnictwo Poznańskie, 2013), 165-166.
} 
ujęcie - dodajmy - wyraźnie skrytykował Lelewel w liście do przyjaciela wysłanym 13 grudnia $1835 \mathrm{r}$. z Brukseli ${ }^{54}$. Mówiąc w drugim tomie Polski malowniczej o chrzcie Litwy, będącym swego rodzaju następstwem objęcia tronu w Polsce przez Jagiełłę, co miało odtąd, jak czytamy, połączyć z woli Bożej nierozerwalnie obydwa państwa ${ }^{55}$, Chodźko nie poruszył zagadnienia wierzeń pogańskich. Wspomniał tylko mimochodem o bałwochwalstwie ${ }^{56}$. W tymże - drugim - tomie brak uzupełnił Andrzej Słowaczyński w artykule ukazującym ziemie pruskie, gdzie m.in. omówił religię ludów bałtyjskich, w zasadzie referując poglądy wyrażone przez Teodora Mateusza Narbutta (1784-1864) w jego Dziejach starożytnych narodu litewskiego ${ }^{57}$. Tematykę wierzeń pogańskich na Litwie podjął później na kartach Polski ozdobniczej Feliks Wrotnowski, który, jak już zasygnalizowaliśmy, poświęcił jej osobny artykuł, przygotowany również na podstawie pracy Narbutta ${ }^{58}$. Wierzenia pogańskie omówił, jak wiadomo, także Forster we wprowadzeniu do części historycznej swego dzieła. W odniesieniu do Polski przedstawił je, podobnie jak Chodźko, w oparciu o Historyę Naruszewicza. Wierzenia litewskie zaprezentował, przywołując wspomnianą pracę Narbutta i artykuł Słowaczyńskiego ${ }^{59}$.

Przyjęcie chrztu przez Mieszka przedstawił Chodźko w niezbyt spójnym logicznie passusie. Władca - idąc za głosem doradców - zdecydował się wytępić pogaństwo i przyjąć chrześcijaństwo, gdyż nie mógł doczekać się potomstwa ze swych wielu pogańskich żon. Decyzja była zatem czysto pragmatyczna, motywowana względami, by się tak wyrazić, płodnościowo-dynastycznymi (przy czym nie dowiadujemy się, dlaczego właśnie przyjęcie chrztu miało zaradzić sytuacji Mieszka - poganina $)^{60}$. Czytamy dalej o następstwach decyzji

\footnotetext{
${ }^{54}$ Lelewel, Listy, t. I, 378, por. Michalski, Dawni Stowianie, 167, 169-172.

55 „Désormais la Pologne et la Litvanie ne formeront plus qu'un meme peuple, et si les événements les désunissent un moment, rien ne peut les séparer: Dieu les a unis, l'acte est cimenté"; La Pologne pittoresque, t. II, 58.

${ }^{56}$ La Pologne pittoresque, t. II, 59.

${ }^{57}$ Dzieje starożytne narodu litewskiego, t. I: Mitologia litewska (Wilno: nakładem A. Marcinowskiego, 1835); La Pologne pittoresque, t. II, 259-262.

${ }^{58}$ La Pologne illustrée, 404-416. Zaznaczmy, że dzieło Narbutta jest ważną pozycją w rozważaniach nad mitologią litewską. Por. A.J. GREIMAS, O bogach i ludziach. Studia z mitologii litewskiej, tłum. B. Marszalik [seria: Biblioteka Klasyków Antropologii] (Kęty: Wydawnictwo Marek Derewiecki, 2007), 196-197, 200-204. Biografię Narbutta opracowała Małgorzata Stolzman w Polskim słowniku biograficznym, t. XXII, red. E. Rostworowski (Wrocław-Warszawa-Kraków-Gdańsk: Zakład Narodowy im. Ossolińskich, Wydawnictwo Polskiej Akademii Nauk, Wrocław 1977), 537-539.

${ }^{59}$ FORSTER, Pologne, 39-40, 46.

${ }^{60}$ „Miéczyslas eut plusieurs épouses païennes, aucune ne lui donna d'enfant; il conçut donc le hardi project, se prêtant aux insinuations de ses conseillers, de détruire l'ancienne religion et d'élever sur ses debris de christianisme. A cette fin il épousa Dombrowka, fille de Boleslas I ${ }^{\mathrm{er}}$, duc de Bohéme.
} 
Mieszka: propozycji małżeństwa z chrześcijanką Dąbrówką, córką króla Czech Bolesława I, przybyciu Dąbrówki na dwór Mieszka wraz z orszakiem, w którym znajdowali się kapłani chrześcijańscy, niszczeniu przejawów kultu pogańskiego na rozkaz Mieszka, chrzcie władcy i jego ślubie z Dąbrówką (5 marca 965 r. w Gnieźnie). Bardzo szybko następuje budowa kościołów (czytamy o dziewięciu obiektach) i organizacji diecezjalnej oraz archidiecezjalnej (dwie archidiecezje), sprowadzenie duchownych z Włoch, Francji i Niemiec, ustanowienie dziesięciny (co zostało opatrzone uwagą: „telle est l'origine du clerge polonais et de ses immenses richesses"; słowa jakby nawiązują do wyrażonego wyżej postulatu Chodźki co do ubóstwa Kościoła). Decyzja Mieszka o porzuceniu pogaństwa, przyjęciu chrześcijaństwa i poślubieniu Dąbrówki została niejako nagrodzona narodzinami ich syna, czyli Bolesława Chrobrego ${ }^{61}$. Informacja nawiązuje do początku omawianego wywodu, stanowiąc jego podsumowanie. Można zauważyć, że zaprezentowany obraz przyjęcia chrześcijaństwa w czasach Mieszka jest obrazem anachronicznym, zawierającym elementy, które zaistniały później czy znacznie później. Chodźko, czerpiąc informacje z Historyi Naruszewicza, ułożył je w ramach, jakie zarysował Anonim tzw. Gall w swej Kronice (siedem pogańskich żon Mieszka, małżeństwo z Dąbrówką, chrzest - nagroda: narodziny Chrobrego; Anonim tzw. Gall I, 5-16, 18-19). Staloryt zamieszczony na początku partii tekstu przedstawiającej „pierwszą epokę”, streszcza „graficznie” główne wątki związane z Mieszkowym chrztem, uwidaczniając na pierwszym planie moment zaślubin książęcej pary - i poniekąd zadziwiając anachronicznością zobrazowanych ubiorów ${ }^{62}$. Podsumowując wywód o przyjęciu chrześcijaństwa, Chodźko podkreśla, że Polacy okazali się gorliwymi wyznawcami nowej religii, gotowymi do jej obrony, czego świadectwem jest datujący się od tych czasów zwyczaj wyciągania szabli do połowy pochwy, gdy czytana jest podczas mszy świętej perykopa ewangeliczna i trzymania tak broni aż do śpiewu „Chwała na wysokości Bogu”. Zwyczaj, wywodzący się z pierwocin chrześcijaństwa w Polsce, trwał, zaznacza Chodźko, aż do upadku państwa w 1795 r. $^{63}$ Podkreślał szczególny - obrończy związek Polaków $\mathrm{z}$ religią katolicką ${ }^{64}$.

Cette princesse professait la religion chrétienne, et son père ne consentit à l'unir, à Miéczyslas qu'autant qu'il embraserait la foi du Christ, en l'imposant à son peuple"; La Pologne pittoresque, t. I, 15.

${ }^{61}$ La Pologne pittoresque, t. I, 15.

${ }^{62}$ La Pologne pittoresque, t. I, ryc. między stronami 12 a 13.

${ }^{63}$ La Pologne pittoresque, t. I, 16.

${ }^{64}$ Lelewel zauważył, że informacja o trwaniu tego zwyczaju do 1795 r. to „śmieszne kłamstwo czy zmyślenie"; Listy, t. I, 378. 
Chrześcijaństwo wprowadzone przez Mieszka zostało ugruntowane za czasów Chrobrego. Polska zyskała bowiem pierwszego męczennika, św. Wojciecha, którego działania misyjne wspierał władca. Kult świętego zaczął rozwijać się w Gnieźnie. Skomponowana przez niego pieśń na cześć Najświętszej Maryi Panny (Bogurodzica) rozbrzmiewała odtąd w polskich kościołach i była śpiewana przez wojska Chrobrego w dniach walki ${ }^{65}$. Świadectwem znaczenia Polski Chrobrego była wizyta Ottona III w Gnieźnie u grobu św. Wojciecha (tzw. Zjazd gnieźnieński) i ustanowienie tamże arcybiskupstwa oraz trzech biskupstw w innych miejscowościach ${ }^{66}$. Informując o powstaniu organizacji diecezjalnej, wikła się autor w sprzeczności. Jak wiadomo, powstanie biskupstw i arcybiskupstw w Polsce umiejscowił w czasach Mieszka I. Zaznaczmy, że na niekonsekwencje wywodu zwrócił nieco złośliwie uwagę Joachim Lelewe ${ }^{67}$. Z podobną niekonsekwencją spotykamy się, czytając o kryzysie państwa wczesnopiastowskiego, kiedy doszło do buntów ludności, skierowanych m.in. przeciw nowej religii i nastąpił nawrót kultów pogańskich. Chrześcijaństwo nie zostało zatem tak mocno ugruntowane w okresie panowania Mieszka i Chrobrego, jak zapewniał autor. Chodźko tłumaczy ekscesy antykościelne tym, że duchowieństwo w Polsce było pochodzenia cudzoziemskiego, nie miało szerszego kontaktu z ogółem ludności, choćby ze względów językowych, opływało w bogactwa (,ces prêtres, comblées de richesses"; za tym stwierdzeniem kryje się postulat ubogiego Kościoła), co jeszcze bardziej powiększało jego wyobcowanie ${ }^{68}$. W tak zarysowanym obrazie dostrzegamy ważny dla autora wątek dotyczący przyczyn kryzysów państwa polskiego i jego słabości. Można sądzić, że Chodźko uważał, iż były one w dużym stopniu spowodowane, powtórzmy, wyobcowaniem elit, także kościelnych, zwłaszcza jeśli ich członkowie byli pochodzenia cudzoziemskiego ${ }^{69}$. W perspektywie cudzoziemskiego pochodzenia elit kościelnych przedstawia Chodźko tzw. sprawę św. Stanisława - któremu przypisuje czeskie pochodzenie: „'évêque de Krakovie Stanislas (Szczepanowski?), Bohémien de naissance” (następnie w tekście: „Le Bohémien Stanislas”). Ukazuje zagad-

\footnotetext{
${ }^{65}$ Zob. wyżej przypis 36 o artykule Wojciecha Sowińskiego.

${ }^{66}$ Kraków, „Wladyslawow” - Wrocław, Kołobrzeg. La Pologne pittoresque, t. I, 35.

${ }^{67} \mathrm{~W}$ cytowanym już liście do Chodźki z 13 grudnia 1835 r. Lelewel wspomniał: „P. 15. col. 2. v. 32. Pytają mnie, co się z tymi urojonymi djecezjami stało, kiedy na p. 35 Bolesław W. nowe eryguje"; Listy, t. I, 378.

${ }^{68}$ La Pologne pittoresque, t. I, 61-62.

${ }^{69}$ Warto przytoczyć w tym kontekście słowa wypowiedziane przy omawianiu wspomnianego kryzysu, a odnoszące się do roli Rychezy - i do roli innych wpływowych cudzoziemek w dziejach Polski: „Rixa, Bone et Marie-Kasimire. Elles n'étaient point Polonaises...!”; La Pologne pittoresque, t. I, 60.
} 
nienie w panoramie walk toczonych przez Bolesława Śmiałego (Boleslas-leHardi), zwłaszcza na Rusi, i skutków tych walk, ubarwiając opowiadanie zawarte w Kronice Mistrza Wincentego ${ }^{70}$. Wystąpienie biskupa przeciw królowi przedstawia (odchodząc od wykładni Mistrza Wincentego) jako skutek intrygi uknutej z poparciem papieża Grzegorza VII oraz księcia czeskiego. Miała to być swego rodzaju odpłata za dążenia - skuteczne, jak sądzi Chodźko - królów polskich do uniezależnienia się od władzy świeckiej papieży. Z drugiej strony książęta czescy (a w ich „tle” biskup Stanisław, Czech) nieprzychylnie patrzyli na to, że Polska osiągnęła wielkość i pragnęli zemsty za podbój Czech przez Chrobrego ${ }^{71}$. Przedstawiając okoliczności wystąpienia biskupa krakowskiego przeciw Bolesławowi Śmiałemu, autor podkreśla różnicę między postępowaniem kleru polskiego wobec króla (posłuszeństwo w sprawach doczesnych) a postawą Stanisława, który rzucił klątwę na władcę w sytuacji, gdy wina tegoż nie była oczywista ${ }^{72}$. Chodźko, powołując się na prace Tadeusza Czackiego (1765-1813) i Jana Wincentego Bandkiego (1783-1846), zaznacza ponadto, że w świetle fragmentu Kroniki Galla biskup był przywódcą spisku przeciw królowi i zamierzał wydać Czechom Kraków ${ }^{73}$. Zabicie Stanisława przez władcę było wyrazem gniewu i porywczości Bolesława, ale też karą za zdradę ${ }^{74}$. Biskup został - dwieście lat po śmierci - ogłoszony świętym na skutek zabiegów papiestwa i cudzoziemskiego kleru i miał to być swoisty akt zemsty na Bolesławie, który pragnął uczynić Polskę wielką oraz ograniczył bogactwa i przywileje tychże cudzoziemskich duchownych ${ }^{75}$. Mówiąc o wygnaniu Śmiałego z kraju, autor

${ }^{70}$ Mistrz Wincenty, Kronika polska, II, 18-19; La Pologne pittoresque, t. I, 115-124.

${ }^{71}$ La Pologne pittoresque, t. I, 125.

72 „D'ailleurs le clergé purement polonais avait pour règle l'obeissance au pouvoir dans les choses temporelles, et les différends devinrent tellement compliqués qu'on ne savait plus si c'était le roi qui méritait des réprimandes, ou ceux contre lesquels ils sévissait”; La Pologne pittoresque, t. I, 125. Wyżej mówił Chodźko o srogim postępowaniu króla wobec zamężnych kobiet, które w czasie gdy ich mężowie byli z Bolesławem na wyprawie ruskiej, wzięły sobie sługi „za mężów”; tamże, 124. Por. opis tej sytuacji przedstawiony w Kronice Mistrza Wincentego (II, 20).

${ }^{73}$ La Pologne pittoresque, t. I, 128. O tych pracach, dotyczących odkrycia i wydania tekstu Kroniki Anonima Galla zob. wstęp Mariana Plezi do tłumaczenia tejże Kroniki; Anonim tzw. Gall, Kronika Polska, przeł. R. Grodecki (Wrocław-Warszawa-Kraków: Zakład Narodowy im. Ossolińskich, 1996), LXXIV-LXXVII. Obszerny artykuł prezentujący postać Czackiego i Liceum Krzemienieckie zamieścił Henryk Edward Choński w drugim tomie La Pologne pittoresque (433-448). Przed początkiem tegoż artykułu (przed stroną 433) znajduje się staloryt przedstawiający wizerunek Czackiego.

${ }^{74}$ La Pologne pittoresque, t. I, 126.

75 „Boleslas, malgré les taches imprimées à son règne, était un roi eminent national. Son idée constant a été de render la Pologne grande et glorieuse par elle - meme; la haine de Rome en était la consequence: les ecclésiastiques étrangers, les prêtres envoys du saint Siège ne pouvaient pardoner 
szerzej przedstawia postać i działalność Grzegorza VII ${ }^{76}$ oraz wskazuje na rolę papieża $\mathrm{w}$ doprowadzeniu do tego wydarzenia (skutki klątwy rzuconej przez Grzegorza na króla) - będącego wyrazem dążeń do osiągnięcia zwierzchnictwa nad Polską ${ }^{77}$.

Dokonana przez Chodźkę w głównej narracji historycznej omawianego dzieła interpretacja wydarzeń odnoszących się do pierwszych wieków Kościoła w Polsce zawiera, jak można zauważyć, kilka zasadniczych wątków. Uwydatnia mianowicie niekorzystny wpływ na losy polskiego państwa i polskiego chrześcijaństwa cudzoziemskich elit kościelnych. Wskazuje na bogactwo materialne tych elit. Zaznacza niekorzystne dla Polski decyzje i działania Stolicy Apostolskiej, podkreślając, że wynikają one w dużej mierze z dążeń papieży do osiągnięcia władzy doczesnej. Autor raczej pozytywnie wypowiada się o postawie rodzimego polskiego duchowieństwa wobec władzy książęcej czy królewskiej, upatrując $\mathrm{w}$ tym wsparcie dla niezależności państwa polskiego i jego wielkości. Pobieżnie - i mętnie - przedstawia Chodźko tworzenie się organizacji diecezjalnej w Polsce, w zasadzie nie informuje o zakonach na ziemiach polskich. Zasygnalizowane ujęcia interpretacyjne dostrzegalne są przy omawianiu w części historycznej Polski malowniczej późniejszych (niezbyt licznie przypomnianych) wydarzeń związanych z Kościołem w Polsce ${ }^{78}$. Chodźko podkreśla pozytywną postawę i działalność edukacyjną polskiego duchowieństwa w XIII stuleciu i ten opis - anachroniczny w odniesieniu do

à un roi qui refusait des prelatures, et c'est done tout ensemble que par vengeance ils firent de Stanislas un saint; deux siécles après sa mort, Innocent IV le reconnut comme tel; on lui érigea un tombeau d'une énorne dimension et tout en argent dans l'église cathèdrale de Krakovie; plus tard le roi Stanislas Poniatowski, pour honorer son patron, fit des embelissements dans son église à Rome et institua un ordre sous son invocation. Cependant ce ne fut que deux et quatre siécles plus tard que le clergé polonaise commença à parler des prétendus miracles de l'évêque Stanislas"; La Pologne pittoresque, t. I, 128. Zwraca w tym fragmencie uwagę informacja o tym, że duchowieństwo polskie bardzo późno po śmierci biskupa Stanisława zaczęło głosić - jakby z przymusu, bez przekonania o domniemanych cudach (,,prétendus miracles”!) z nim związanych.

${ }^{76}$ La Pologne pittoresque, t. I, 126-128.

77 „Des que Grégoire apprit la mort de l'évêque de Krakovie, ses idées de domination se réveillent. Il saisit cette circonstance pour flétrir, par son pouvoir pontifical, la conduit de Boleslas; il lança son anathema contre lui"; La Pologne pittoresque, t. I, 128.

${ }^{78}$ Mieszko Stary przyznaje przywileje immunitetowe klerowi, co zjednuje mu jego uznanie; La Pologne pittoresque, t. I, 289. Mieszko Stary zmienia się w złego władcę pod wpływem cudzoziemskiego biskupa, nieprzyjaciela Polski, Henryka Kietlicza („Un Tanger, un enemi de la Pologne, s'empare de l'esprit de Miéczyslas et dirigea toutes ses action"); La Pologne pittoresque, t. I, 289. Postać wrogiego Polsce biskupa krakowskiego Muskaty; La Pologne pittoresque, t. I, 350. Żyjący w dostatkach kler potępia ubogich biczowników; La Pologne pittoresque, t. II, 12. 
tego wieku - zdaje się odnosić także do kolejnych stuleci ${ }^{79}$. Bardziej szczegółowo omawia stosunki z papiestwem, zwracając uwagę na motywowane korzyściami finansowymi (świętopietrze) decyzje dotyczące Polski ${ }^{80}$. Nieprzychylna dla papiestwa opinia w sprawie jego postawy i działań wobec Polski zostanie przez Chodźkę niejako pogłębiona - i podsumowana - w Polsce ozdobniczej. Czytamy o pozytywnym ustosunkowaniu się papieża do „zapytania”, które wysłała doń Maria Teresa: czy Austria, kraj katolicki, może wziąć udział w rozbiorze Polski, kraju także katolickiego. Odpowiedź dana Cesarzowej była tym boleśniejsza, że Polacy ślepo ufali papieżowi ${ }^{81}$.

W narracji historycznej Polski malowniczej poruszył Chodźko sprawę chrztu Litwy i powstania w tym państwie organizacji diecezjalnej ${ }^{82}$. Te informacje niejako wskazywały, że ważnym elementem jedności Rzeczypospolitej jest wyznaniowo i organizacyjnie katolicyzm ${ }^{83}$. Jednakże autor nie

${ }^{79}$ W XIII stuleciu duchowieństwo polskie było na ogół zacne, z wyjątkiem kilku biskupów i dostojników („Le clergé en général était honorable, si j’en excepte quelques évêques et les somnités"). Szerzyło oświatę i odrzucało obce wpływy co do edukacji. Szkoły prowadzone przez duchownych były przesiąknięte „duchem narodowym” („les college dirigés par les prêtres étaient animés d'un esprit tout national"). Uczono w nich w języku ojczystym historii Polski, wpajano przywiązanie do kraju. Kraj stawał się jednością - co było ziszczeniem planu Bolesława (Chrobrego?!); La Pologne pittoresque, t. I, 344.

${ }^{80}$ Brak poparcia Benedykta XII dla ustaleń zjazdu w Wyszehradzie z 1335 r. (obawa o utratę świętopietrza z Pomorza): „Benoît XII désapprouva la convention de Wissegrad, comme attentoire à la justice et au bien de l'Etat, et sourtout, [podkreślone w tekście - L.W.] à l'autorité du siége appostolique. Le pape ne pouvait voir de bon oeil la cession de la Poméranie, car il en tirait de grands revenus, qui l'aidaient à compenser ce que les Bohémiens et les Allemands refusaient de lui payer; il blâma donc les déterminations du roi des Polonais, et refusa net de se désister de l'impôt du denier de saint Pierre”. Dalej zaś czytamy: „Ce n'était pas encore tous ses griefs: il ne pardonait pas à Kasimir la ligue soutenue contre Louis, empereur d'Allemagne [cesarz Ludwik IV - L.W.], par les rois de Bohême, de Hongrie et le roi des Polonais; car Louis s'humiliait devant la puissance de pape. Toutefois il renait homage à Kasimir sur la manière dont il administrait la justice, et il nomma une commission pour résoudre l'affaire des chevaliers Teutoniques"; La Pologne pittoresque, t. II, 5. Podana informacja o niechęci Benedykta XII nie odpowiada rzeczywistości, ale idzie „po linii” narracji Chodźki o stosunku papiestwa do Polski. Por. J. WyroZumSKI, Kazimierz Wielki (Wrocław: Zakład Narodowy im. Ossolińskich, 1982), 53-64.

Kazimierz Jagiellończyk rezygnuje ze starań u Stolicy Apostolskiej w sprawie kanonizacji królowej Jadwigi, gdyż trzeba było bardzo drogo opłacić tę sprawę w Rzymie. Zebrane pieniądze przeznaczono na obronę Ojczyzny przed Krzyżakami (wojna trzynastoletnia?); La Pologne pittoresque, t. II, 63.

Działania wysłanników papieża, zwłaszcza kardynała Cesariniego, przed i w czasie wyprawy warneńskiej; La Pologne pittoresque, t. II, 116-118.

Działania nuncjuszy apostolskich w czasie rozwoju protestantyzmu w Rzeczypospolitej; La Pologne pittoresque, t. II, 309-310.

${ }^{81}$ La Pologne illustrée, 169.

${ }^{82}$ La Pologne pittoresque, t. I, 326; t. II, 57, 59.

${ }^{83}$ Por. też La Pologne pittoresque, t. II, 129-139 - o kościele katedralnym w Wilnie; La Pologne pittoresque, t. II, 300 - o arcybiskupstwie w Rydze. 
pomija informacji o rozwoju wyznań reformowanych w państwie polsko-litewskim, a nawet stosunkowo obszernie omawia zagadnienie, przedstawiając panowanie Zygmunta Augusta. Zwraca przy tym uwagę na postawę i działanie polskich biskupów i nuncjuszy papieskich wobec protestantyzmu. Podkreśla, że w Rzeczypospolitej osiągnięto pokój religijny ${ }^{84}$. Polityczne następstwa istnienia w państwie polsko-litewskim różnic wyznaniowych i związanych z nimi ograniczeń praw dysydentów omawia Chodźko, przedstawiając wydarzenia z lat 1766-1768 w okresie panowania Stanisława Augusta Poniatowskiego. Zaznacza, że innowiercy, zabiegając o poparcie Katarzyny II i Repnina, działającego zgodnie z wolą imperatorowej, dawali tym samym wygodny pretekst do rozgrywania wewnętrznych spraw polskich przez stronę rosyjską. Podkreśla zarazem, że „godna pożałowania” sprawa dysydentów miała charakter polityczny właśnie, a nie religijny, nie wiązała się z tolerancją wyznaniową panującą w Rzeczypospolitej. Została niewłaściwie odebrana za granicą jako swego rodzaju awantura religijna ${ }^{85}$. Opisując - pobieżnie sprawę dysydentów, a następnie omawiając konfederację barską, Chodźko charakteryzuje w tym kontekście postawę niektórych ówczesnych duchownych. Ostro ocenia działania Gabriela Podoskiego (późniejszego prymasa) i jego wysługiwanie się Repninowi ${ }^{86}$. Mówi o patriotycznej postawie biskupów Kajetana Sołtyka i Józefa Andrzeja Załuskiego (wzmiankuje o wywiezieniu ich „do Moskwy” na rozkaz Repnina, zaznaczając, że była to niesłychana nieprawość) oraz Adama Krasińskiego ${ }^{87}$.

Znaczenie sprawy dysydentów w kontekście wzmocnienia wpływów rosyjskich w Rzeczypospolitej w początkowych latach panowania Stanisława Augusta omawia także Mierosławski w części historycznej trzeciego tomu Polski malowniczej. Charakteryzuje istotę ich żądań, zaznaczając, że choć były słuszne, to jednak w tamtym czasie stanowiły narzędzie w rękach nieprzyjaciół Rzeczypospolitej ${ }^{88}$. Zaznaczmy, że omawiając przebieg sejmu z 1766 r.,

${ }^{84}$ La Pologne pittoresque, t. II, 293, 305-310. Swego rodzaju kontrastem dla sytuacji religijnej w Rzeczypospolitej jest opis prześladowań, m.in. wobec duchowieństwa prawosławnego, wszczętych w państwie moskiewskim przez Iwana Groźnego; La Pologne pittoresque, t. II, 380-392.

85 „C'est dès lors que fut introduite la deplorable affaire des dissidents, où la tolerance religieuse servait uniquement de prétexte à la tzarine pour amener à fin ses desseins. L'Europe presque tout entière s'y laissa tromper, et considérant la question des dissidents polonais comme une querelle de religion, elle ne la prit pas au sérieux”; La Pologne illustrée, 148.

${ }^{86}$ „L'abbé Podoski, aventurier capable de tout, et dévoré de l'ambition des premières dignités eccléstiastiques, mit toutes les resources de ses intrigues au service de l'ambassade moskovite"; La Pologne illustrée, 148.

${ }^{87}$ La Pologne illustrée, 150-151, 186.

${ }^{88}$ La Pologne pittoresque, t. III, 217, 226-232. Tu także, na stronie 226, przywołanie sądu Lelewela dotyczącego dopuszczenia niekatolików do urzędów. 
formułuje bardzo krytyczny osąd ówczesnych politycznych działań Czartoryskich $^{89}$. Podkreśla również znaczenie Podoskiego (zmiennego w swych sympatiach politycznych) jako gorliwego stronnika - i suflera - poczynań Repnina. Podobnie jak Chodźko, wspomina o postawie i losach Sołtyka i Krasińskiego ${ }^{90}$. Mierosławski, opisując losy państwa polsko-litewskiego po śmierci Jana III, zwraca uwagę na polityczną rolę biskupów, zwłaszcza kardynała prymasa Michała Radziejowskiego ${ }^{91}$, w latach bezkrólewia oraz podczas kolejnych elekcji; szerzej omawia przy tym - także ze względu na czytelnika francuskiego - sprawę wyboru księcia Conti w 1697 r. oraz Stanisława Leszczyńskiego ${ }^{92}$. Autor charakteryzuje również kulturową działalność księży katolickich, zwłaszcza w zakresie oświaty. Poświęca uwagę postaci Stanisława Konarskiego, wzmiankuje o działalności braci Załuskich ${ }^{93}$.

W części historycznej dzieła Forstera wydarzenia odnoszące się do Kościoła nie są liczne. Autor podaje je bez szerszej otoczki interpretacyjnej. Bardziej powściągliwie wyraża się o stosunku Stolicy Apostolskiej do Polski. Obraz początków Kościoła w Polsce nakreślony przez Forstera w dużym stopniu podobny jest do tego, który przedstawił Chodźko. Forster jednak zaznacza, że mimo tylu wysiłków Mieszka chrześcijaństwo, choć umocnione przez Chrobrego, rozprzestrzeniało się w Polsce powoli. Słabe zakorzenienie nowej religii ujawniło się w latach 1034-1040, w czasie nawrotu pogaństwa, gdy Polska przeżywała kryzys. Dopiero za czasów Kazimierza I (Odnowiciela) chrześcijaństwo w Polsce na dobre zwyciężyło (tamże). Jak wspomniano, Forster mówi także o chrzcie Litwy za czasów Jagiełły ${ }^{94}$. Wzmiankuje o wcześniejszym chrzcie Mendoga (,Mindowe”) z 1252 r., przyjętym z Rzymu z pobudek utylitarnych - Innocenty IV przyznał władcy koronę królewską. Mendog

${ }^{89}$ „Cette terrible famille, qui depuis vingt ans pesait sur les destinées de la république de tout le poids de son égoïsme et de son ambition, se trouva enfin humiliée et vaincue par les instruments même dont elle s'était servi pour asservir son pays"; La Pologne pittoresque, t. III, 230.

${ }^{90}$ La Pologne pittoresque, t. III, 224 [niewłaściwie 384], 225, 231, 239.

91 „Prince, cardinal, Michel Radzieiowski, énigme de vices et de splendeur pour laquelle les codes de l'histoire n'ont pas encore trouvé de sentence, mais dont la vie tout entire semble avoir eu pour sens moral cet axiome dérisoire, pant de fois répété depuis, que la Pologne ne pouvait exister que par l'anarchie et l'absence de pouvoir"; La Pologne pittoresque, t. III, 54.

${ }_{92}$ La Pologne pittoresque, t. III, 1-12, 54-57, 102-107, 162, 165, 182-183. Należy zaznaczyć, że między stronami 8 a 9 znajduje się rycina wykonana przez Pilińskiego, przedstawiająca elekcję króla na polu elekcyjnym na Woli. Jest to jeden ze stalorytów, w którym ujawnia się artyzm wykonawcy.

${ }^{93}$ La Pologne pittoresque, t. III, 123-124. Rycina ukazująca Stanisława Konarskiego między stronami 122 i 123; Andrzeja Załuskiego (o niezłych walorach artystycznych) między stronami 124 i 125. W tymże tomie, jak wiadomo, znajduje się też staloryt przedstawiający Ignacego Krasickiego, między stronami 162 i 163 . Zob. wyżej przypis 42.

${ }^{94}$ Forster, Pologne, 79. 
powrócił jednak do pogaństwa, zrażony intrygami krzyżaków - wyznających katolicyzm (s. 65). O działaniach papiestwa niekorzystnych dla Polski, a powodowanych dążeniem do utwierdzenia władzy świeckiej papieży, czytamy w opisie panowania Bolesława Śmiałego. Władca koronował się na króla, nie zabiegając o to u Grzegorza VII, przez co podważył papieskie prerogatywy w tym zakresie i zamanifestował swą niezależność. Naraził się zatem na gniew Grzegorza. Rzym bowiem pragnął od dawna umocnić swój wpływ na Polskę. Bolesław wzbudził nadto niezadowolenie wśród cudzoziemskich duchownych, gdyż pozbawił ich dostojeństw w Polsce. Jak można zauważyć, taka interpretacja jest jakby echem (choć dosyć słabym) tego, co znajdujemy w Polsce malowniczej. Swoistą konsekwencją koronacji królewskiej Bolesława Śmiałego była tzw. sprawa św. Stanisława. Forster przedstawia ją, odwołując się, tak jak Chodźko, do prac T. Czackiego i J.W. Bandkiego. Biskup krakowski, któremu jednak Forster nie przypisuje czeskiego pochodzenia, został przedstawiony jako zuchwały dostojnik oddany Stolicy Apostolskiej, podburzający lud przeciw królowi. Ufny w poparcie „Watykanu" rzucił klątwę na Bolesława i obłożył interdyktem kościoły Krakowa. Król w reakcji na postępowanie biskupa zabił go w kościele na Skałce. Forster znacznie uprościł w stosunku do treści podanych w Polsce malowniczej tło i przebieg konfliktu. Biskup Stanisław został ukazany jako gorliwy „wykonawca" papieskiego gniewu, spowodowanego samowolną koronacją Bolesława $^{95}$. Klątwa rzucona przez Grzegorza VII na króla i interdykt nałożony na Polskę spowodowały, że Bolesław został wygnany. Papież osiągnął to, że odtąd bez zgody Stolicy Apostolskiej władca Polski nie mógł się koronować (s. 53). Dopiero Bonifacy VIII pozwolił na kolejną koronację - Przemysławowi II (s. 68). Forster jeszcze dwukrotnie obszerniej wzmiankuje o wpływie papiestwa na losy Polski. Prezentując początki panowania Władysława Łokietka, mówi o jego potajemnej pielgrzymce do Rzymu w roku jubileuszowym 1300 i o przychylnej dla niego decyzji Bonifacego VIII co do objęcia tronu w Polsce (s. 69-70). Ukazuje także ,intrygi Rzymu” (,intrigues de Rome"), które w rezultacie doprowadziły do klęski warneńskiej. Wspomina przy tym o osłabieniu $\mathrm{w}$ tym czasie wszechwładzy kościelnej („L’omnipotence ecclésiastique"), spowodowanym tzw. niewolą awiniońską papieży, schizmą zachodnią i wystąpieniem Husa (s. 84-85). W Polsce znajdujemy także obszerniejszą informację o jednym z zakonów, mianowicie o jezuitach.

${ }^{95}$ „La colère du pontifie fut grande à cette nouvelle” - na wieść o tejże koronacji. Buntownika spotkała kara z rąk króla (,toua de sa propre main l'ambitieux qui, sous un habit saint, cachait une âme devouée à l'intrigue et à la rébellion"); FORSTER, Pologne, 53. 
Forster poświęca im uwagę przy opisie panowania Stefana Batorego. Mówi bowiem o powierzeniu jezuitom przez króla kierowania Uniwersytetem Wileńskim. Decyzja Batorego, wypływająca z dobrych intencji, spowodowała jednak przykre dla Polski skutki ${ }^{96}$. Jezuici, sprowadzeni za czasów Zygmunta Augusta, obrośli w bogactwa, rozszerzyli swe wpływy, byli nietolerancyjni wobec wyznań niekatolickich. Ocena roli jezuitów w historii Rzeczypospolitej nie jest jednak jednoznacznie negatywna. Forster podkreśla, że zakon przyczynił się wydatnie do rozwoju nauki i sztuki ${ }^{97}$.

Jak wspomniano, Forster z niejaką dumą mówi o pokoju religijnym w Rzeczypospolitej (zob. też s. 163). Przykładem dla Europy, zaznacza, są postanowienia w tym zakresie podjęte na sejmie 1573 r. (konfederacja warszawska; s. 112). Sprawy wyznaniowe mogą być jednak pretekstem do wywołania konfliktu i osłabienia Polski (s. 112, 139). Forster przywołuje w tym kontekście wydarzenia dotyczące dysydentów (s. 139).

W prezentacji wydarzeń odnoszących się do Kościoła, podanych w częściach historycznych omawianych dzieł istnieją, jak można spostrzec, pewne różnice w zakresie stylu (Chodźko i Mierosławski przedstawiają je bardziej „kwieciście”, bardziej „opowiadająco” niż Forster, który stara się być zwięzły), szczegółowości i interpretacji. Nie są to jednak, co do interpretacji, różnice zasadnicze. Sprowadzają się do innego rozłożenia akcentów, wyeksponowania takich czy innych okoliczności, które towarzyszyły opisywanym sprawom. „Perspektywy interpretacyjne”, które przyjęli Chodźko i Forster, ukazując - w wyborze - wydarzenia $\mathrm{z}$ historii polskiego chrześcijaństwa, widoczne są wyraźniej, jak już wspomniano, kiedy przeanalizujemy opisy chrztu Polski oraz śmierci św. Stanisława i wygnania Bolesława Śmiałego.

Jak wiadomo, niektóre zagadnienia dotyczące Kościoła są w omawianych dziełach uszczegółowione w artykułach zamieszczonych poza częścią historyczną. W pierwszym tomie La Pologne pittoresque znajduje się interesujące dopełnienie ważnego aspektu tych dziejów. Artykuł autorstwa Chodźki wyraźniej niż w wyżej przedstawionych wydarzeniach uwydatnia walkę papiestwa o wpływy i władzę w Polsce. Odwołuje się do licznego materiału faktograficznego. Podkreśla (po raz kolejny), że celem dążeń papieży było podporządkowanie Polski ich władzy doczesnej. Pomimo wielu zabiegów te dążenia nie powiodły się, w dużym stopniu dzięki poparciu, jakie znajdowali

\footnotetext{
${ }^{96}$ „1579. Étienne Batory, qui contribua tant à la gloire et à la prosperité du pays, commit cependant une grande faute, et cette faute, que la bonne intention excuse, eut des suites bien fầcheuses"; FORSTER, Pologne, 104.

${ }^{97}$ Zyskało na tym Wilno, jak czytamy; Forster, Pologne, 104.
} 
polscy władcy wśród polskich dostojników kościelnych. Papieże byli w rezultacie traktowani jako ci, którzy nie tyle posiadają władzę absolutną, lecz jako reprezentujący jedność chrześcijan ${ }^{98}$.

Autor wskazuje ponadto, że działania inkwizycji, którą uważa za narzędzie realizacji „watykańskich” planów absolutystycznych" ${ }^{99}$, również nie przyniosły w Polsce oczekiwanych rezultatów. Inkwizycja nie doprowadziła do zniszczenia tolerancji religijnej, wyrażającej się m.in. - jak przedstawia to Chodźko (a wtóruje mu Forster) - w tolerowaniu istnienia herezji: waldensów, biczowników, wiklefistów, dulcynian... Chodźko traktuje herezje jako przejawy obrony praw człowieka (!) i wolności myśli ${ }^{100}$. Inkwizycja natomiast to narzędzie - $\mathrm{w}$ domyśle papieskie narzędzie - tłumienia postępów w tym zakresie ${ }^{101}$. Polska, nie dopuszczając, aby inkwizycja rozwinęła na jej terytorium swe działania, była ostoją wolności przekonań obywatelskich i politycznych - jako pierwsza spośród państw europejskich. W podsumowaniu tych rozważań Chodźko przypomina encyklikę Cum primum, godzącą $w$ te wartości, potępiającą zryw listopadowy i wzywającą Polaków do posłuszeństwa wobec prawowitej władzy - moskiewskiej, Polaków przywiązanych do swego narodowego Kościoła, do swej Ojczyzny, do wolności i tolerancji. Encyklika, jak zaznacza Chodźko, nie wywarła wrażenia na narodzie polskim i polskim duchowieństwie. Polacy nie zaprzestali obrony wiary swych ojców ${ }^{102}$. Uwagi Chodźki ujawniają, jakie „skutki interpretacyjne” miała encyklika dla zawartego w La Pologne pittoresque ujęcia historii Kościoła w Polsce, a zwłaszcza dla ujęcia relacji ze Stolicą Apostolską; widoczne są one, jak wyżej wspomniano, także w dziele Forstera (choć autor

98 „Les rois de Pologne, en accordant par leur pouvoir les hautes dignités ecclésiastiques, affaiblissaient l'influence papale; en un mot, ils considéraient les papes, non comme un pouvoir absolu, mais bien comme les représentants de l'unité chretienne"; La Pologne pittoresque, t. I, 406.

${ }^{99}$ „Le Vatican ne pouvait souffrir longtemps l'esprit d'indépendance qui guidait la Pologne”; La Pologne pittoresque, t. I, 407.

${ }^{100}$ Podobną opinię wyraża Chodźko w krótkim artykule poświęconym zamkowi w Lipowcu, gdzie więziono heretyków; La Pologne pittoresque, t. II, 254.

101 „L'héresie considerée historiquement, était la défense des droits de l'homme et de la liberté de la pensée. L'inquisition fut inventée, soufferte, autorisée pour réprimer tout élan progresif'; $L a$ Pologne pittoresque, t. I, 408.

102 „Un fait est venu, de nos jours, prouver encore l'atachement des Polonais au culte de leur église nationale, à ce culte où la patrie, la liberté et la tolérance se confondent. Au mois de juillet 1832, l'autocratie du Vatican donna la main à l'atocratie de Saint-Pétersbourg pour condemner la révolution du 29 novembre 1830. Les letters encycliques du pape, ordonnant aux Polonais soumission à la légitimité mosqovite, ne produisirent au cun effet sur la nation et le clergé, qui ne cessent de défendre avec foi et énergie la religion de leurs pères"; La Pologne pittoresque, t. I, 408. 
nie wspomina o encyklice w materiale dotyczącym czasów polistopadowych). Bez trudu zauważamy je w artykule Jana Wysłoucha, opublikowanym w trzecim tomie La Pologne pittoresque, mówiącym o duchowieństwie katolickim (s. 89-96). Tekst w dużym stopniu poświęcony został przypomnieniu postanowień i działań papieży - w większości niekorzystnych dla Polski. Wysłouch zaznacza, że w nowszym, tak tragicznym okresie dziejów Rzeczypospolitej, w XVIII stuleciu, wpływy polityczne Rzymu reprezentowali jezuici. Natomiast patriotyczną postawę przyjęli pijarzy, dominikanie i członkowie innych zakonów. Znamienne jest to zestawienie: wpływy papiestwa a patriotyzm oraz prawdziwa religia ${ }^{103}$. W Polsce malowniczej znajdują się, jak wiadomo, artykuły - w większości autorstwa Chodźki - ukazujące ważne aspekty życia religijnego. Przedstawiają mianowicie sanktuaria na Jasnej Górze, na Świętym Krzyżu i w Kalwarii (Zebrzydowskiej), sygnalizując tym samym istotne wymiary polskiej religijności - maryjny i, w mniejszym zakresie, pasyjny. Wspominają także o kulcie patronów Polski związanym ze świątyniami w Gnieźnie, Krakowie i Wilnie ${ }^{104}$. Szerzej omawiają postać i kult bł. Salomei (pustelnia Salomei w Grodzisku koło podkrakowskiej Skały; kościół św. Franciszka w Krakowie z grobowcem bł. Salomei $)^{105}$. Omawiają również ośrodki dawnego życia zakonnego - klasztory kamedułów (Bielany) i benedyktynów w Tyńcu ${ }^{106}$. Trzeba jednak zaznaczyć, że w tych artykułach dominują informacje odnoszące się do usytuowania omawianych obiektów w kontekście krajobrazowym, do ich rozplanowania (kaplice, ołtarze) oraz walorów architektonicznych i zabytkowych, a także do związanych z tymi świątyniami wydarzeń z dziejów Polski, zwłaszcza od II połowy XVIII stulecia. Forster nie zamieszcza w swym dziele, jak wiadomo, osobnych rozdziałów poświęconych świątyniom. Przypomnijmy jednak, że w jego Polsce znajduje się znacznie bogatsze niż w La Pologne pittoresque i w La Pologne illustrée omówienie zwyczajów religijnych, mające pewną wartość etnograficzną ${ }^{107}$.

103 „A l'influence politique du saint Siège represénté alors par les Jésuites, il oposa [le clergé catholique - L.W.] l'influence patriotique des Piiaristes, des Dominicains et d'autres congrégations déduites de son propre sein et animées de l'amour de la vraie religion"; La Pologne pittoresque, t. III, 95.

${ }^{104}$ Zob. wyżej przypis 34. Artykuł o Kalwarii (Zebrzydowskiej) autorstwa F.K. Godebskiego.

${ }^{105}$ Zob. wyżej przypis 34. Artykuł o pustelni w Grodzisku napisany został przez Olimpię Chodźkową.

${ }^{106}$ Zob. wyżej przypis 34. Artykuł o Bielanach został, jak wiadomo, napisany przez Forstera. Chodźko dał dwa artykuły o Tyńcu, jeden zamieszczając w pierwszym tomie Polski malowniczej, a drugi w Polsce ozdobniczej.

${ }^{107}$ Zob. wyżej przypis 40; por. informację z przypisu 37. 
Zaprezentowane dzieła ukazują, jak można stwierdzić, zróżnicowany obraz Kościoła w Polsce/Rzeczypospolitej. W wywodzie historycznym zauważamy swoistą perspektywę interpretacyjną przedstawianych wydarzeń, w dużej mierze wyznaczoną, powtórzmy, przez reakcję na encyklikę Cum primum. Warto w tym miejscu przytoczyć syntetyzującą ocenę skutków publikacji encykliki, sformułowaną przez Mieczysława Żywczyńskiego: „ostre wyrażenia [zawarte w encyklice - L.W.] o polskim ruchu insurekcyjnym przetrwały długo w świadomości Polaków, podsycały wśród nich antyklerykalizm, osłabiły odrodzenie religijne na emigracji" ${ }^{108}$.

Autorzy (zwłaszcza Leonard Chodźko) wskazując na, by tak rzec, przyrodzoną Polsce wolność i niezależność, uwydatniają przy prezentacji wydarzeń z historii polskiego Kościoła niekorzystne dla tejże wolności działania papiestwa i obcego duchowieństwa, raczej negatywnie oceniają działania jezuitów. Wynikają stąd postulaty, by Kościół w Polsce stał się swego rodzaju Kościołem narodowym, gallikańskim, uwolnionym od różnego rodzaju wpływów politycznych Rzymu, potrafiącym ustrzec swą niezależność, wzmacniając przez to niezależność Rzeczypospolitej. Podobne koncepcje głoszono już w Polsce w II połowie XVIII stulecia, przedstawił je m.in. prymas Podoski ${ }^{109}$. Trudno jednak wyraźnie stwierdzić, na ile inspirowały one Chodźkę i Forstera oraz ich współpracowników. Bardziej istotne wydaje się natomiast pytanie, $\mathrm{w}$ jakim stopniu wspomniane postulaty były bliskie ówczesnym poglądom, które głosił wówczas ks. Félicité de Lamennais (1782-1854) i jego współpracownicy - m.in. Charles de Montalembert oraz ks. Jean-Baptiste Lacordaire - na łamach czasopisma „L'Avenir”, zamkniętego w listopadzie $1831 \mathrm{r}$. (poglądy głoszone w „L'Avenir” zostały potępione przez Grzegorza XVI w encyklice Mirari vos z 15 sierpnia 1832 r.; przypomnijmy, że encyklika Cum primum została wydana dwa miesiące wcześniej). W Polsce malowniczej, w mniejszym stopniu w Polsce ozdobniczej oraz w Polsce zawarto interesujący materiał mówiący o miejscach kultu religijnego

${ }^{108}$ M. ŻYWCZYŃSKI, „Watykan i Metternich a sprawa polska w latach 1836-1848” [odbitka ze Sprawozdań Towarzystwa Naukowego Warszawskiego 32, z. 1-3 (1939), Wydział II]: 33; zob. też tamże, 31 (o reakcjach księcia Adama Czartoryskiego na publikację tejże encykliki).

${ }^{109}$ E. RostworowsKi, „Podoski Gabriel Jan”, w Polski słownik biograficzny, t. XXVII, red. E. Rostworowski (Wrocław-Warszawa-Kraków-Gdańsk-Lódź: Zakład Narodowy im. Ossolińskich, Wydawnictwo Polskiej Akademii Nauk, 1983), 155-156. Zob. też W. KONOPCZYŃSKI, Dzieje Polski nowożytnej, oprac. J. Dzięgielewski, M. Nagielski, [t. II] (Warszawa: Instytut Wydawniczy Pax, 2003), 615; S. LiTAK, „Kościół w Polsce w okresie Oświecenia do 1795 roku”, w Historia Kościoła, t. IV [1715-1848], red. L.J. Rogier, G. de Bertier de Sauvigny, J. Hajjar, tłum. T. Szafrański (Warszawa: Instytut Wydawniczy Pax, 1987), 408. 
i o niektórych przejawach religijności w Rzeczypospolitej. Materiał został wzbogacony ilustracjami, mającymi niekiedy sporą wartość artystyczną. Stosunkowo szerokie uwzględnienie tematyki kościelnej w tych dziełach, i to zarówno w wymiarze historycznym, jak i kultowym, w połączeniu z prezentacją plastyczną, należy uznać za spore osiągnięcie koncepcyjne, wykonane $\mathrm{z}$ rozmachem. Tego rodzaju ujęcia nie były bowiem poprzednio realizowane. Bardzo duża popularność omawianych prac niejako skłania do dalszych badań nad propagowaniem i kształtowaniem przez nie obrazu historii i kultury Rzeczypospolitej, w tym również obrazu historii Kościoła, wśród odbiorców zagranicznych, zwłaszcza francuskich. Ważne byłoby też umiejscowienie Polski malowniczej, Polski ozdobniczej oraz Polski w ówczesnych polskich nurtach historiograficznych - wskazanie, na ile zawarta w tych dziełach główna narracja historyczna i tematyka oraz treść artykułów „towarzyszących" nawiązują, zwłaszcza jeśli chodzi o prezentację historii Kościoła, do („oświeceniowej”) szkoły naruszewiczowskiej, na ile zaś odzwierciedlają („romantyczną”) „szkołę lelewiczowską”. Dzieła te były publikowane zaznaczmy na końcu - w latach wyraźnego ożywienia postaw religijnych i szczerze dewocyjnych, a też poniekąd mistycznych wśród części emigrantów polskich we Francji. Postaw tworzących atmosferę, w której wyrosły popularność i znaczenie Andrzeja Towiańskiego (przebywającego w Paryżu w latach 1841-1842), i - z drugiej strony - ukształtowały się decyzje o założeniu zgromadzenia zmartwychwstańców. Trudno jednoznacznie stwierdzić, czy nakreślony w Polsce malowniczej, w Polsce ozdobniczej i w Polsce niezbyt chlubny obraz działań papieży był swego rodzaju „dziejopisarską reakcją" na te postawy, w których niejednokrotnie wyrażały się przywiązanie do Stolicy Apostolskiej, akceptacja jej autorytetu i postanowień.

\section{BIBLIOGRAFIA}

ŹRÓDŁA

ANONIM tzw. GALL. Kronika polska, przeł. R. Grodecki. Wrocław-Warszawa-Kraków: Zakład Narodowy im. Ossolińskich, 1996.

Forster, Charles. Pologne (L'Univers pittoresque, t. 10). Paris: Firmin Didot Frères, 1841.

La Pologne historique, littéraire, monumentale et illustrée [...]. Rédigée Par Une Societé de Littérateurs sous la direction de Leonard Chodzko, ancient rédacteur en chef de la Pologne historique, littéraire, monumentale et pittoresque. Paris: Bureau Central, 1839-1841.

La Pologne historique, littéraire, monumentale et pittoresque [...]. Rédigée Par Une Sociéte de Littérateurs Polonais sous la direction de Léonard Chodzko, publiée par Ignace - Stanislas Grabowski, t. I. Paris: Bureau Central, 1835-1836. 
La Pologne historique, littéraire, monumentale et pittoresque [...]. Rédigée par Une Societé de Littérateurs Polonais [sous la direction de Léonard Chodzko, publiée par Ignace - Stanislas Grabowski], t. II. Paris: Bureau Central, 1837-1838.

La Pologne historique, littéraire, monumentale et pittoresque [...]. Rédigée par Une Societé de Littérateurs Polonais [publiée par Ignace - Stanislas Grabowski], t. III. Paris: Bureau Central, $1839-1842$.

LELEWEL, Joachim. Listy emigracyjne Joachima Lelewela, wyd. H. Więckowska, t. I-III. Kraków: Polska Akademia Umiejętności, 1948-1952.

Malte-Brun, Conrad. Tableau de la Pologne ancienne et moderne, contenant la description de ce pays [...]. Paris: H. Nicolle et Comp., 1807.

Malte-Brun, Conrad. Tableau de la Pologne ancienne et moderne, sous les rapports géographiques [...]. Nouvelle édition [...] augmentée [...] par Leonard Chodzko, t. I-II. Paris: H. Fournier, 1830.

Mistrz Wincenty KadŁUBeK. Kronika polska, przeł. B. Kürbis. Wrocław: Zakład Narodowy im. Ossolińskich, 2003.

NARBUTT, Teodor. Dzieje starożytne narodu litewskiego. t. I: Mitologia litewska. Wilno: nakładem A. Marcinowskiego, 1835.

\section{OPRACOWANIA}

BANACH, Andrzej. Polska ksiązka ilustrowana 1800-1900. Kraków: Wydawnictwo Literackie, 1959.

Bibliografia literatury polskiej. Nowy Korbut, red. I. Śliwińska i in., t. VII-IX. Warszawa: Państwowy Instytut Wydawniczy, 1968-1972.

BoRkowskA, Władysława. „Chodźko Leonard”. W Polski słownik biograficzny, t. III, red. W. Konopczyński, 386-388. Kraków: Polska Akademia Umiejętności, 1937.

Bronowski, Franciszek. Idea gminowładztwa w polskiej historiografii. Geneza i formowanie sie syntezy republikańskiej J. Lelewela. Łódź-Wrocław: Zakład Narodowy im. Ossolińskich, 1969.

CZAPSKA, Maria. „Chodźkowa Olimpia Ludwika z Maleszewskich”. W Polski stownik biograficzny, t. III, red. W. Konopczyński, 389-390. Kraków: Polska Akademia Umiejętności, 1937.

EstreICHER, Karol. Bibliografia polska XIX stólecia [sic], t. I-III. Kraków: nakładem Akademii Umiejętności, 1872-1876.

FranCASTel, Pierre. La Pologne pittoresque. Grenoble: B. Arthaud, 1934.

GŁĄBIŃSKI, Stanisław. „Choński Henryk”. W Polski słownik biograficzny, red. W. Konopczyński, t. III, 419. Kraków: Polska Akademia Umiejętności, 1937.

GrABSKI, Andrzej Feliks. Troski i nadzieje. Z dziejów polskiej myśli społecznej i politycznej XIX wieku. Łódź: Wydawnictwo Łódzkie, 1981.

GRABSKI, Andrzej Feliks. Zarys historii historiografii polskiej. Poznań: Wydawnictwo Poznańskie, 2003.

Greimas, Algirdas Julien. O bogach i ludziach. Studia z mitologii litewskiej, tłum. B. Marszalik [seria: Biblioteka Klasyków Antropologii]. Kęty: Wydawnictwo Marek Derewiecki, 2007.

JASKUŁA, Roman. Karol Forster. Emigracyjny działacz, pisarz i wydawca 1800-1879. Kraków: Wydawnictwo Naukowe Akademii Pedagogicznej, 2002.

KALEMBKA, Sławomir. Wielka Emigracja 1831-1863. Toruń: Wydawnictwo Adam Marszałek, 2003. 
KIENIEwICZ, Stefan. „Mierosławski Ludwik”. W Polski słownik biograficzny, t. XX, red. E. Rostworowski, 812-815. Wrocław-Warszawa-Kraków-Gdańsk: Zakład Narodowy im. Ossolińskich, Wydawnictwo Polskiej Akademii Nauk, 1975.

KonopCZYŃSKI, Władysław. Dzieje Polski nowożytnej, oprac. J. Dzięgielewski, M. Nagielski, [t. I-II]. Warszawa: Instytut Wydawniczy Pax, 2003.

LITAK, Stanisław. „Kościół w Polsce w okresie Oświecenia do 1795 roku”. W Historia Kościoła, t. IV [1715-1848], red. L.J. Rogier, G. de Bertier de Sauvigny, J. Hajjar, thum. T. Szafrański, 395-453. Warszawa: Instytut Wydawniczy Pax, 1987.

ManteufflowA, Maria. „Maleszewski (Maliszewski) Piotr Paweł Jan”. W Polski stownik biograficzny, t. XIX, red. E. Rostworowski, 306-308. Wrocław-Warszawa-Kraków-Gdańsk: Zakład Narodowy im. Ossolińskich, Wydawnictwo Polskiej Akademii Nauk, 1974.

MARKIEWICZ, Zygmunt i SIVERT Tadeusz. Melpomena polska na paryskim bruku. Teatralia polskie we Francji w XIX wieku. Warszawa: Państwowe Wydawnictwo Naukowe, 1973.

MerzBach, Henryk. Prace numizmatyczne Joachima Lelewela w Belgii. Kraków: nakładem Towarzystwa Numizmatycznego, 1889 [odbitka z „Wiadomości Numizmatyczno-Archeologicznych”].

MichalSKI, Maciej. Dawni Stowianie w tradycji polskiej I połowy XIX w. W poszukiwaniu tożsamości wspólnotowej. Poznań: Wydawnictwo Poznańskie, 2013.

RostworowsKi, Emanuel. „Podoski Gabriel Jan”. W Polski słownik biograficzny, t. XXVII, red. E. Rostworowski, 149-161. Wrocław-Warszawa-Kraków-Gdańsk-Lódź: Zakład Narodowy im. Ossolińskich, Wydawnictwo Polskiej Akademii Nauk, 1983.

Stolzman, Małgorzata. „Narbutt (Ostryk-Narbutt) Teodor Mateusz”. W Polski stownik biograficzny, t. XXII, red. E. Rostworowski, 537-539. Wrocław-Warszawa-Kraków-Gdańsk: Zakład Narodowy im. Ossolińskich, Wydawnictwo Polskiej Akademii Nauk, 1977.

StraszewsKA, Maria. Życie literackie Wielkiej Emigracji we Francji 1831-1840. Warszawa: Państwowy Instytut Wydawniczy, 1970.

Tyrowicz, Marian. „Forster Karol”. W Polski słownik biograficzny, t. VII, red. W. Konopczyński, 67-69. Kraków: Polska Akademia Umiejętności, Polska Akademia Nauk, Wydawnictwo Zakładu Narodowego im. Ossolińskich, 1948-1958.

WERNICKI, Aleksander. Leonard Chodźko i jego prace. Krótki rys biograficzny i naukowy. Lwów: Księgarnia Polska, 1880.

WierzBickA, Maria. Dawne syntezy dziejów Polski. Rozwój i przemiany koncepcji metodologicznych [seria: Monografie z Dziejów Nauki i Techniki, t. XCV). Wrocław: Zakład Narodowy im. Ossolińskich, 1974.

WyrozUMSKI, Jerzy. Kazimierz Wielki. Wrocław: Zakład Narodowy im. Ossolińskich, 1982.

ZıóŁEK, Jan. Studia nad myśla polityczna Wielkiej Emigracji. Napoleon I i Napoleon III. Lublin: Towarzystwo Naukowe KUL, 1995.

ŻYCHOwSKI, Marian. Ludwik Mierosławski 1814-1878. Warszawa: Państwowe Wydawnictwo Naukowe, 1963.

ŻYWCZYŃSKI, Mieczysław. „Watykan i Metternich a sprawa polska w latach 1836-1848”, [odbitka ze Sprawozdań Towarzystwa Naukowego Warszawskiego 32, z. 1-3 (1939), Wydział II]: 27-37. 


\title{
KOŚCIÓŁ KATOLICKI WE FRANCUSKOJĘZYCZNYCH UJĘCIACH \\ HISTORII - GEOGRAFII - KULTURY POLSKI/RZECZYPOSPOLITEJ OPRACOWANYCH WE FRANCJI W LATACH 1835-1842 PRZEZ EMIGRANTÓW POLSKICH
}

\begin{abstract}
Streszczenie
W artykule zostały przedstawione trzy obszerne dzieła powstałe i wydane we Francji po powstaniu listopadowym, a opracowane w środowisku polskich emigrantów. Dzieła te prezentowały czytelnikowi francuskiemu systematyczny wykład historii Polski/Rzeczypospolitej. Zawierały poza tą główną treścią artykuły mówiące o geografii Rzeczypospolitej oraz o kulturze i zagadnieniach dotyczących religii. Posiadały liczne ilustracje. Najobszerniejsze spośród tych dzieł to La Pologne pittoresque, Polska malownicza; wydane zostało w trzech tomach w latach 1835-1845. W latach 1839-1841 ukazało się kolejne dzieło omawiające wspomniane tematy, La Pologne illustrée, Polska ozdobnicza. Głównym redaktorem tych prac był Leonard Chodźko (1800-1871). Natomiast w $1840 \mathrm{r}$. Karol Forster (1800-1879) opublikował Pologne. Dzieła zyskały dużą popularność. W artykule zajęto się problemem prezentacji roli Kościoła katolickiego w historii Polski/Rzeczypospolitej, a także prezentacji różnych elementów życia religijnego. Wskazano na kilka zasadniczych wątków ideowych dostrzeganych w tejże prezentacji. Podkreślono zauważalną obecność zagadnień religijnych we wspomnianych dziełach, co pozytywnie wyróżnia je na tle ówczesnych prac podobnego rodzaju.
\end{abstract}

Słowa kluczowe: Leonard Chodźko; Karol Forster; obraz Kościoła katolickiego w XIX w.

THE CATHOLIC CHURCH IN FRENCH-LANGUAGE APPROACHES

TO THE HISTORY - GEOGRAPHY - CULTURE OF POLAND/THE REPUBLIC OF POLAND, DEVELOPED IN FRANCE IN 1835-1842 BY POLISH EMIGRANTS

Su m mary

The article presents three extensive works written and published in France after the November Uprising, and compiled in the milieu of Polish emigrants. These works presented the French reader with a systematic lecture on the history of Poland/the Republic of Poland. Apart from this main content, they contained articles about the geography of the Republic of Poland as well as about culture and issues related to religion. They had numerous illustrations. The most extensive of these works is La Pologne pittoresque, Picturesque Poland; was published in three volumes in the years 1835-1845. In the years 1839-1841 another work was published on the aforementioned topics, $L a$ Pologne illustrée, Ornamental Poland. The chief editor of these works was Leonard Chodźko (1800-1871). And in 1840 Karol Forster (1800-1879) published Pologne. The works gained great popularity. The article deals with the problem of presenting the role of the Catholic Church in the history of Poland/the Republic of Poland, as well as presenting various elements of religious life. Several basic ideological threads were identified in this presentation. The noticeable presence of religious issues in the aforementioned works was emphasized, which positively distinguishes them from other works of a similar type at that time.

Keywords: Leonard Chodźko; Karol Forster; the image of the Catholic Church in the 19th century. 